\title{
Review
}

\section{KYNA Derivatives with Modified Skeleton; Hydroxyquinolines with Potential Neuroprotective Effect ${ }^{\dagger}$}

\author{
Bálint Loórinczi ${ }^{1,2}$ (D) and István Szatmári 1,2,3,*(D) \\ 1 Institute of Pharmaceutical Chemistry, University of Szeged, Eötvös u. 6, H-6720 Szeged, Hungary; \\ lorinczi.balint@szte.hu \\ 2 Institute of Pharmaceutical Chemistry, Interdisciplinary Excellence Center, University of Szeged, \\ H-6720 Szeged, Hungary \\ 3 MTA-SZTE Stereochemistry Research Group, Hungarian Academy of Sciences, Eötvös u. 6, \\ H-6720 Szeged, Hungary \\ * Correspondence: szatmari.istvan@szte.hu \\ $+\quad$ This article is dedicated to the memory of Prof. Dr. Ferenc Fülöp, supervisor, former research group leader \\ and institute head.
}

check for updates

Citation: Lőrinczi, B.; Szatmári, I. KYNA Derivatives with Modified Skeleton; Hydroxyquinolines with Potential Neuroprotective Effect. Int. J. Mol. Sci. 2021, 22, 11935. https:// doi.org/10.3390/ijms222111935

Academic Editor: José MarcoContelles

Received: 28 September 2021

Accepted: 29 October 2021

Published: 3 November 2021

Publisher's Note: MDPI stays neutral with regard to jurisdictional claims in published maps and institutional affiliations.

Copyright: (c) 2021 by the authors. Licensee MDPI, Basel, Switzerland. This article is an open access article distributed under the terms and conditions of the Creative Commons Attribution (CC BY) license (https:// creativecommons.org/licenses/by/ $4.0 /)$.

\begin{abstract}
Kynurenic acid (KYNA) is an endogenous neuroprotective agent of increasing importance Several derivatives have already been synthesized, bearing an abundance of functional groups attached to the main skeleton in different positions. Several of these compounds have already been tested in biological evaluations, with several of them targeting the same receptors and biological effects as KYNA. However, these modified compounds build upon the unmodified KYNA skeleton leaving a possible route for the synthesis of new, potentially neuroprotective derivatives with heteroatom-containing ring systems. The aim of this review is to summarize the syntheses of KYNA derivatives with altered skeletons and to pinpoint an appealing transformation for future medicinal lead molecules.
\end{abstract}

Keywords: kynurenic acid; modified hydroxyquinolines; Conrad-Limpach reaction; neuroprotection; modified Mannich reaction

\section{Introduction}

KYNA (kynurenic acid) is an endogenous product of the tryptophan (TRP) metabolism, a pathway known to be responsible for the production of nicotinamide adenine dinucleotide (NAD) and NAD phosphate [1,2]. In this pathway, TRP is converted into various compounds, including L-kynurenine, which can be metabolized in two separate ways. One furnishes KYNA, whereas the other gives 3-hydroxykynurenine and quinolinic acid, the precursors of NAD [3,4].

Among the important features of KYNA, it is one of few known endogenous excitatory amino acid receptor blockers with a broad spectrum of antagonistic properties in supraphysiological concentrations. It is well established that KYNA has a high affinity towards N-methyl-D-aspartate (NMDA) receptors. Moreover, it has recently been disclosed that KYNA shows an even higher affinity towards positive modulatory binding sites at $\alpha$-amino-3-hydroxy-5-methyl-4-isoxazolepropionic acid (AMPA) receptor [5].

Since KYNA is a neuroprotective agent able to prevent neuronal loss following excitotoxic, ischemia-induced, and infectious neuronal injuries [6,7], there has recently been increasing interest in the synthesis and pharmacological studies of KYNA derivatives. The substitution of KYNA at positions 5-8 was achieved by starting from the corresponding aniline via the modified Conrad-Limpach method [8-10]. The hydroxy group at position four was transformed to ether [10-12] or amine functions [13-15], while the carboxylic function at position two was mostly modified into the corresponding esters [10-12] or amides [16-21]. 
These modifications on the 4-hydroxyquinoline-2-carboxylic acid skeleton can either be (i) additions or modifications of functional groups at different positions or (ii) modifications in the benzo-fused 4-oxo-1,4-dihydropyridine-2-carboxylic acid skeleton itself. The latter can also be grouped into two distinct subgroups: the exchange of carbons to heteroatoms or the change of B ring size. While aspect (i) was already reviewed in 2009 [21], modifications on the B ring have not yet been collected. The aim of this review is to summarize the syntheses of KYNA derivatives modified at the B ring that either contain a heteroatom in the B ring and/or have a different ring size (Figure 1). In the future, these compounds may provide a basis for the synthesis of new KYNA derivatives and thus a variety of candidates for medicinal use.

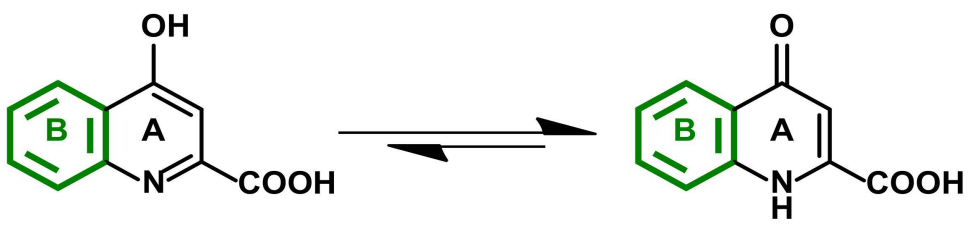

Figure 1. Structure of KYNA.

With this in mind, the secondary aim of this review is to collect new substitution reactions carried out on the kynurenic acid skeleton. These new modifications may provide possibilities to improve pharmacological characteristics of the base compound, such as water solubility, blood-brain-barrier penetration and/or biological effects.

The synthesis of modified quinoline structures has a wide variety of possible methods [22]. However, with the 2-carboxylic and 4-oxo functions taken into consideration, the possible routes are narrowed down to a small range of nucleophilic substitutions or additions followed by intramolecular ring closure. Since the syntheses, from this aspect, differ only in a few cases, they have been categorized on the basis of the type and position of the heteroatom in the modified skeletons.

\section{Synthesis of Functionalized and Heteroatom Containing KYNA Derivatives}

\subsection{Nitrogen-Containing Ring Systems}

\subsubsection{Pyridine- and Pyrimidine-Fused Ring Systems}

A possible route for the preparation of functionalized quinoline structures is the Conrad-Limpach synthesis. During the procedure described by Max Conrad and Leonhard Limpach, an aniline is reacted with $\beta$-keto esters to form an intermediate Schiff-base. In the second step, this intermediate undergoes a thermal intramolecular ring closure yielding the final quinolone derivative [23-25]. As the synthesis of the intermediate can be achieved with several methods, variations of the reaction using different aniline derivatives or electrophiles to synthesize the intermediate have been disclosed.

One of the first reviews on the synthesis of KYNA derivatives bearing modified B rings (Figure 2. I) was published by Williamson et al. The reaction starting out from aniline derivative 1a used ethyl ethoxalylacetate as $\beta$-keto ester, yielding intermediate $2 \mathrm{a}$. Then the product was stirred in boiling diphenyl ether $\left(\mathrm{Ph}_{2} \mathrm{O}\right)$ to achieve ring closure yielding 1,5-naphthyridine derivative 3a (Scheme 1, Table 1) [26].

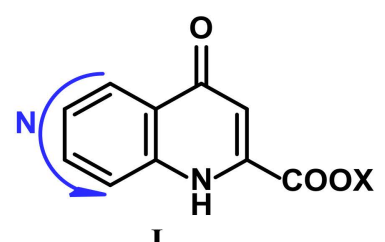

I

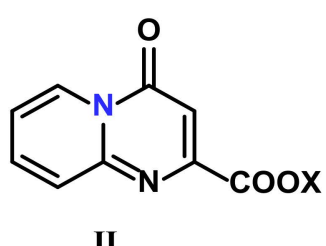

II

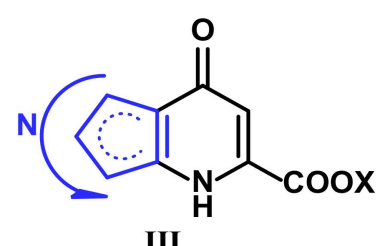

III

Figure 2. General formula for the Nitrogen-containing ring system. 


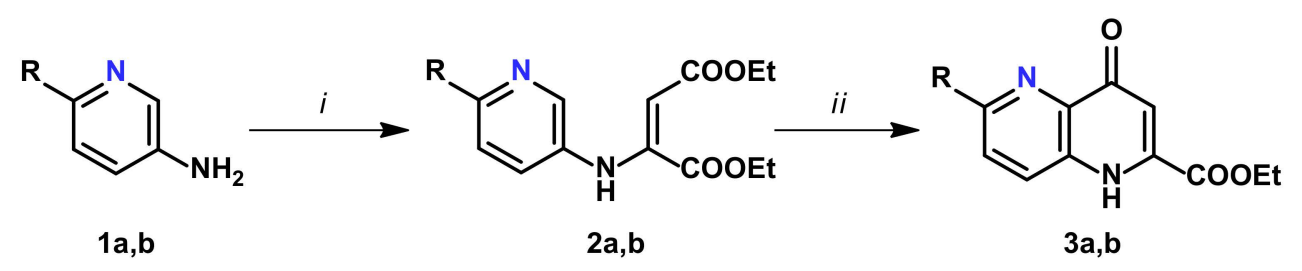

$\mathrm{R}=\mathrm{OMe}, \mathbf{a} ; \mathrm{Cl}, \mathbf{b}$

Scheme 1. Synthesis of 1,5-naphthyridine derivatives $3 \mathbf{a}, \mathbf{b}$.

Table 1. Reaction conditions for the preparation of 1,5-naphthyridine derivatives.

\begin{tabular}{|c|c|c|c|c|c|}
\hline Reaction & Reagent & Solvent & Temperature $\left({ }^{\circ} \mathrm{C}\right)$ & Reaction Time & Yield (\%) \\
\hline \multirow[b]{3}{*}{$i$} & \multirow{2}{*}{ diethyl oxalacetate } & glacial acetic acid & $40-50{ }^{\circ} \mathrm{C}$; r.t. & 4 h; overnight & 2a $43 \%$ [26] \\
\hline & & neat & $90{ }^{\circ} \mathrm{C}$ & $7 \mathrm{~h}$ & $\mathbf{2 b} 21 \%$ [27] \\
\hline & $\begin{array}{c}\text { sodium } \\
\text { (Z)-1,4-diethoxy-1,4- } \\
\text { dioxobut-2-en-2-olate }\end{array}$ & glacial acetic acid & r.t. & 2.5 days & $\mathbf{2 b} 23 \%[28]$ \\
\hline \multirow{3}{*}{$i i$} & \multirow{3}{*}{-} & $\mathrm{Ph}_{2} \mathrm{O}$ & reflux & $10+10 \mathrm{~min}$ & 3a $84 \%$ [26] \\
\hline & & Dowtherm A & $210^{\circ} \mathrm{C}$ & $5 \mathrm{~h}$ & $3 \mathbf{b} 34 \%[27]$ \\
\hline & & $\mathrm{Ph}_{2} \mathrm{O}$ & reflux & $15+20 \mathrm{~min}$ & $3 b 29 \%[28]$ \\
\hline
\end{tabular}

The same method was utilized 50 years later by Nakamoto et al. [27] and Feng et al. [28] in two distinct patents to synthesize the intermediates of $3 \mathbf{b}$ by using either diethyl oxalacetate or its alkali salt, sodium (Z)-1,4-diethoxy-1,4-dioxobut-2-en-2-olate, respectively. The synthesized compounds were later transformed to potential antifungal [27] and antimalarial [29] or potential farnesoid X receptor modulators (Scheme 1 and Table 1) [28,30].

In the case of the synthesis of 1,6-naphthyridine derivatives, the method presented in the literature [31] involves a procedure different from the one described by Conrad and Limpach. Pyridine with an active $\alpha$-methyl function (4), which can be regarded as an acetophenone derivative [32], is reacted with dimethyl oxalate in the presence of excess MeONa needed to shift the reaction toward the ring closure (Scheme 2).<smiles>CC(=O)c1c(N)ccnc1C(F)(F)F</smiles>

4<smiles>CC(=O)C(=O)Nc1ccnc(C(F)(F)F)c1C(C)(F)F</smiles>

5

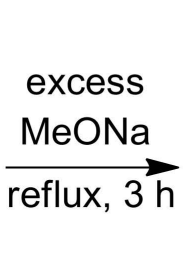<smiles>COC(=O)c1cc(=O)c2c(C(F)(F)F)nccc2[nH]1</smiles>

Scheme 2. Synthesis of naphthyridine derivative 6 via acetophenone analog 4 .

Regarding the synthesis of 1,7-naphthyridine derivatives, the literature is scarce: only two patents mention these compounds. In both cases, the derivatives were used to broaden the 4-hydroxyquinoline-2-carboxylic acid scaffold of the final bioactive compound with an additional heteroatom-containing skeleton (8, 10, 11, 13, Schemes 3 and 4) [33,34]. However, the patents neither described the synthesis of the naphthyridine skeleton nor cited an appropriate reference. 


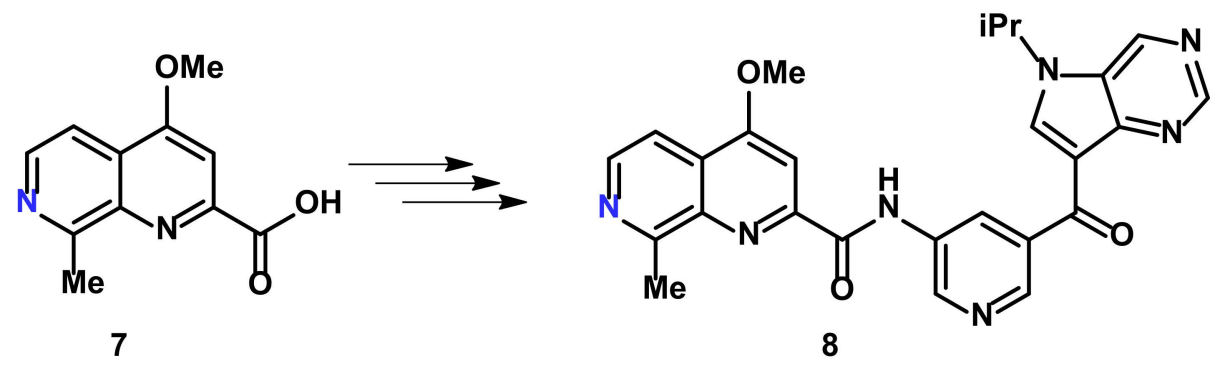

Scheme 3. 1,7-Naphthyridine derivative with possible kinase-inhibiting effect.<smiles>CC#CCCCCCCCCCCCC</smiles><smiles>CCOc1cc(C(=O)N2CCC3(CC2)CC(=O)c2cc(-c4cncc(-c5nnn[nH]5)c4)ccc2O3)nc2c(C3CC3)nccc12</smiles><smiles>CCOc1cc(C(=O)N2CCC3(CC2)CC(=O)c2cc(-c4cncc(C(=O)O)c4)ccc2O3)nc2c(C3CC3)nccc12</smiles><smiles>CC#CCCCCCCCCCCO</smiles><smiles>NC(=O)c1cncc(-c2ccc3c(c2)C(=O)CC2(CCN(C(=O)c4cc(OCCO)c5ccnc(C6CC6)c5n4)CC2)O3)c1</smiles>

Scheme 4. 1,7-Naphthyridine derivatives $(\mathbf{1 0}, \mathbf{1 1}, \mathbf{1 3})$ with possible acetyl coenzyme A inhibiting effect.

The synthesis of 1,8-naphthyridine, containing a carboxylic function at position C-2 and a hydroxy function at position C-4, was first carried out by Weiss et al. [35]. The reaction is a perfect example of the Conrad-Limpach procedure [23-25] using a substituted $\beta$-keto ester. For the formation of the Schiff base, $\alpha$-ethoxalylpropionate (a $\beta$-keto ester) was applied, yielding 16; however, its isolation in high purity was unsuccessful (Scheme 5).<smiles>CCOC(=O)C(C)C(=O)OCC</smiles>

Scheme 5. Synthesis of C-3 methyl-substituted 1,8-naphthyridine derivative 16. 
The modification used in the synthesis of many KYNA derivatives [36] was also applied for the synthesis of 1,8-naphthyridine derivatives. This method involves the use of acetylene derivatives for the synthesis of enamine intermediates through Michael addition. Tonetti et al. [37] utilized this method to synthesize 19 by applying dimethylacetylenedicarboxylate (DMAD) as an electrophilic reagent. However, the precise conditions of the synthesis are unclear, as the original paper could not be found, and the reaction scheme was put forward based on the information gathered from Chemical Abstracts (Scheme 6).<smiles>CC(=O)Nc1cccc(N)n1</smiles>

Scheme 6. Proposed synthesis of 1,8-naphthyridine derivative 19.

However, judging from the work of Huc et al., it is safe to conclude that the reaction depicted in Scheme 7 is correct, since the research group managed to synthesize the same compound from the same starting materials (Scheme 7) [38]. Derivative 19 was later used to create oligomers that were investigated in the hope of finding foldamers with a chemical space as vast as their aliphatic counterparts (namely, $\alpha$-peptides) [39-42].

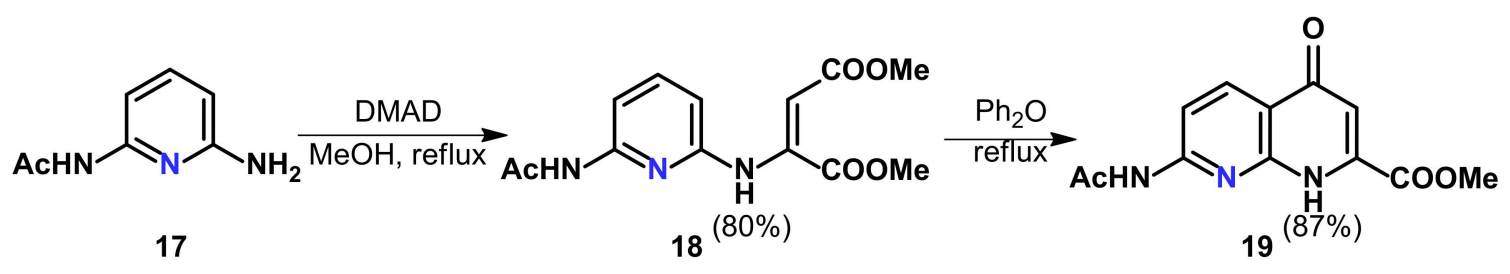<smiles>CC#CCCCCCCOc1cc(C(=O)Nc2ccc3c(OCC(C)C)cc(C(=O)OCC(C)C)nc3n2)nc2nc(N(N)C(C)(C)C)ccc12</smiles>

Scheme 7. Synthesis of 1,8-naphthyridine derivative 19 and its use as a foldamer building block.

The same method was applied by Dohmori et al. [43] during the synthesis of different potentially antimicrobial agents (against Trichomonas vaginalis). Pyrrolidine-substituted 1,8-naphthyridine 23 was synthesized using functionalized aminopyridine 21 and DMAD, albeit with a low yield of $11 \%$. Nevertheless, it further supports the idea that these compounds can be synthesized with this modified Conrad-Limpach procedure (Scheme 8). 


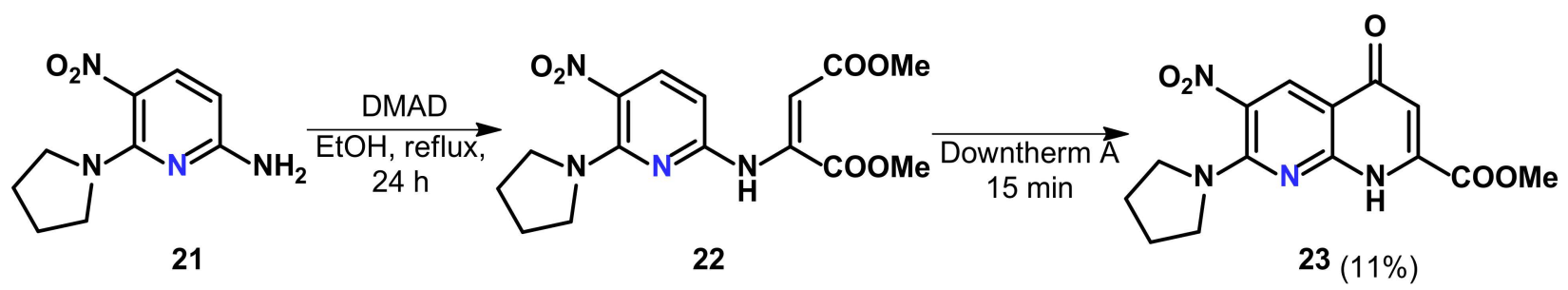

Scheme 8. Synthesis of pyrrolidine substituted 1,8-naphthyridine 23.

The use of DMAD to carry out the Michael addition and, subsequently, the synthesis of different pyrimidine-containing skeletons have also been investigated. The first method published describes the synthesis of pyrido [3,2- $d$ ]pyrimidine skeleton [44]. This method was later optimized by Rosowsky et al. by decreasing the reaction time of the intramolecular ring closure from $45 \mathrm{~min}$ to a reaction time as short as $3 \mathrm{~min}$ (Scheme 9) [45]. The method was later cited by patents for the synthesis of compounds exhibiting PI3K inhibitory activities [46].<smiles>[R16]C(C)(C)Nc1c[nH]c(=O)[nH]c1=O</smiles>

Scheme 9. Synthesis of pyrido[3,2-d]pyrimidine derivative 26.

The synthesis of the pyrido[2,3- $d$ ]pyrimidine skeleton has also been described; however, in the first publication, it was only mentioned as a desired product. The research group tried to apply the same Michael addition with DMAD. However, the reaction yielded the C-5 carbonylated derivative of 6-aminouracil (28, Scheme 10) [47]. Sakaguchi et al. tried to achieve the ring closure by changing $N, N$-dimethylformamide (DMF) to $\mathrm{MeOH}$. Still, both at room temperature and under reflux conditions, the formation of the same maleate intermediate $\mathbf{2 9}$ was observed. Subsequently, it was transformed in either DMF or $\mathrm{MeOH}$ under reflux to 2-oxo-4-carboxylic acid derivative 30. However, in $\mathrm{MeOH}$, the formation of a minimal amount of the 4-oxo derivative $\mathbf{3 1}$ also took place. This observation, in combination with the fact that solvents used for other Conrad-Limpach ring closure steps [Dowtherm A, 1,2-dichlorobenzene (DCB)] were not investigated, indicates that the synthesis with a better yield may be possible (Scheme 10) [48].

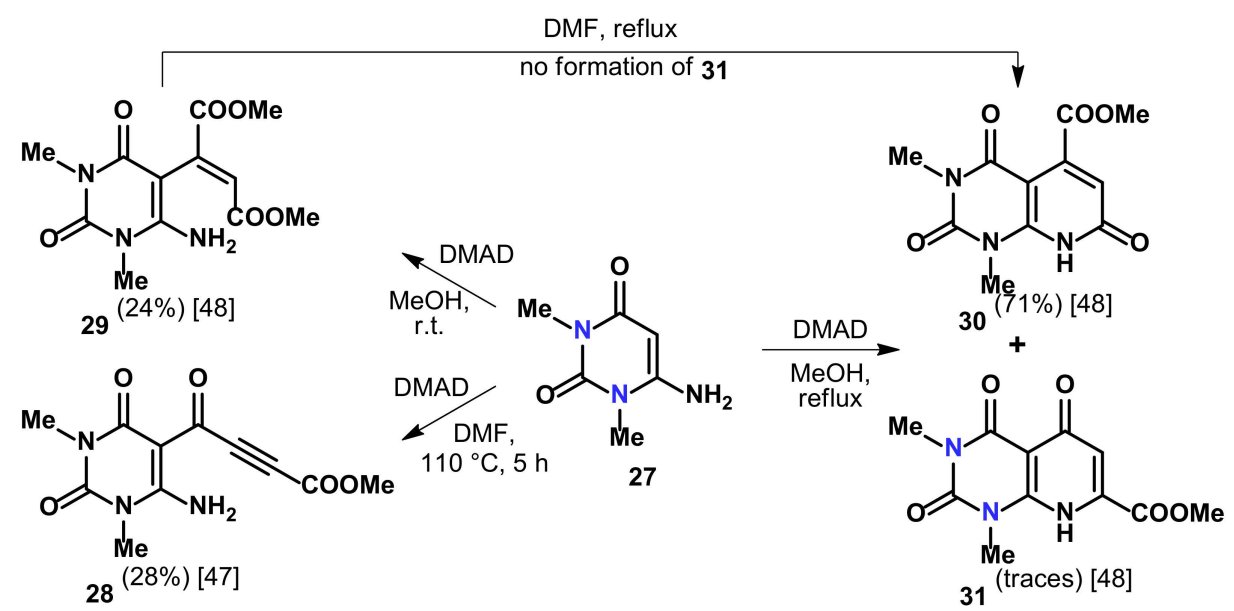

Scheme 10. Possible methods for the synthesis of pyrido[2,3- $d]$ pyrimidine derivative 31. 
Dorokhov et al. used their method for 1,6-naphthyridine 6 [32] to synthesize a wide variety of pyrimidine analogues (33a,b, $\mathbf{3 4 a - g}$ ) as well (Scheme 11) [49].

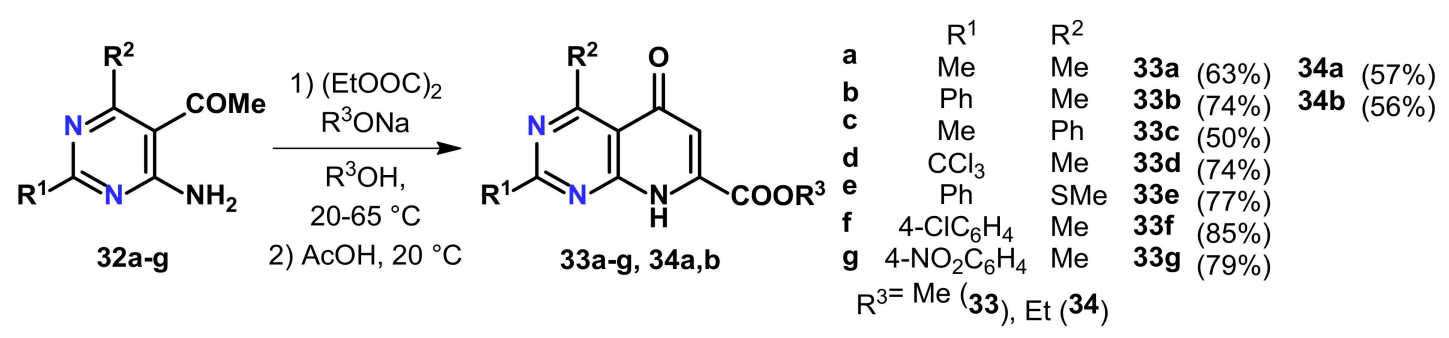

Scheme 11. Synthesis of pyrido[2,3- $d$ ] pyrimidine derivatives $33 \mathbf{a}-\mathbf{g}, \mathbf{3 4 a}, \mathbf{b}$ via acetophenone derivatives $\mathbf{3 2 a - g}$.

\subsubsection{N-Bridgehead Annulations}

For the synthesis of $4 H$-pyrido[1,2-a]-pyrimidin-4-one skeleton (Figure 2. II), several methods have been described. Earlier reports include the reaction of 2-aminpyridine with different reagents under varied conditions ranging from reactions at $250{ }^{\circ} \mathrm{C}$ using Meldrum's acid [50] through reactions in $\mathrm{AcOH}$ (under reflux conditions) [51] or with the use of metal catalysts [52] to milder reactions in ethanol at reflux temperature [53]. However, the synthesis of quinoline compounds bearing both the same bridgehead nitrogen and the 4-oxo and 2-carboxylic functions required different conditions. In this subsection, the methods on the synthesis of the specific skeleton until now are collected.

As a straightforward approach, the Conrad-Limpach procedure can also be applied to synthesize the required derivatives. Diethyl 2-methyl-3-oxosuccinate, as a functionalized $\beta$-keto ester, was used by Jaenicke et al. [54] along with bismuth trichloride as a catalyst to synthesize KYNA analog 36, methyl-substituted at C-3 containing bridgehead nitrogen (Scheme 12). Regarding catalysts, the reaction showed high selectivity toward bismuth trichloride compared to other salts, such as zinc chloride or iridium chloride.

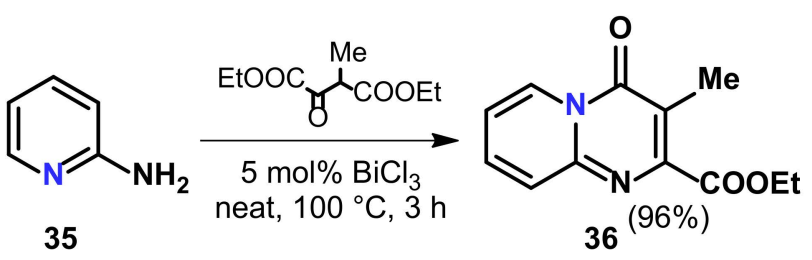

Scheme 12. Synthesis of C-3 functionalized N-bridgehead derivative 36 using metal catalyst.

It has been shown in two articles that the synthesis can also be carried out without the use of a toxic metal catalyst. Starting from the same $\beta$-keto ester, the synthesis of both $\mathbf{3 6}$ and the 6-bromo-substituted derivative $\mathbf{3 8}$ could be achieved (Scheme 13) $[55,56]$. However, the inaccurate description of the methods (no given $w / w \%$ and $\mathrm{mol} \%$ of $\mathrm{TsOH}-\mathrm{SiO}_{2}$ catalyst) and the lower yields overshadow the results.
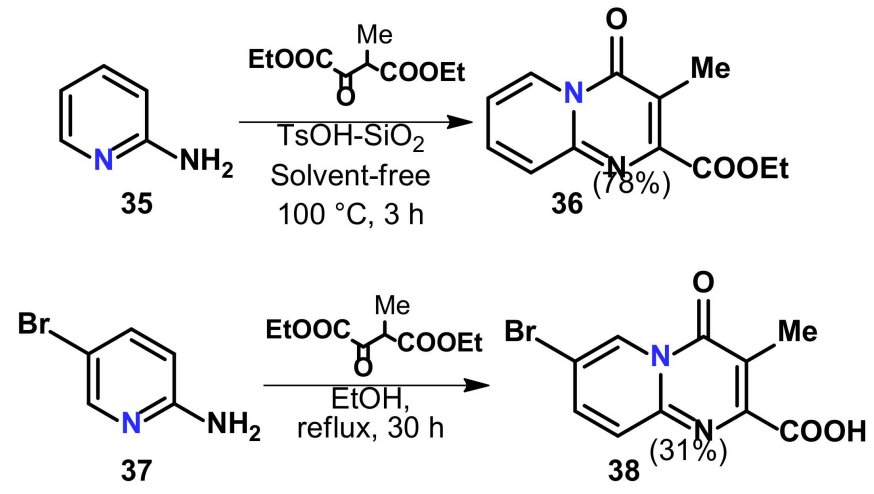

Scheme 13. Metal-free synthesis of compound 36 and bromo-substituted derivative 38. 
Similar to the synthesis of pyridine-fused derivatives, the $\beta$-keto ester electrophile can be replaced by other electron-deficient reagents, such as DMAD. One of the reactions described used the acetylene derivative in water. The reaction carried out at room temperature yielded the unsubstituted $N$-bridgehead derivative 40 in $6 \mathrm{~h}$ (Scheme 14) [57]. This procedure was later applied in a patent to create derivatives inhibiting MeTTL3 activity, and in this way, also inhibiting proliferative disorders, such as cancer, autoimmune, infectious or inflammatory diseases [58].

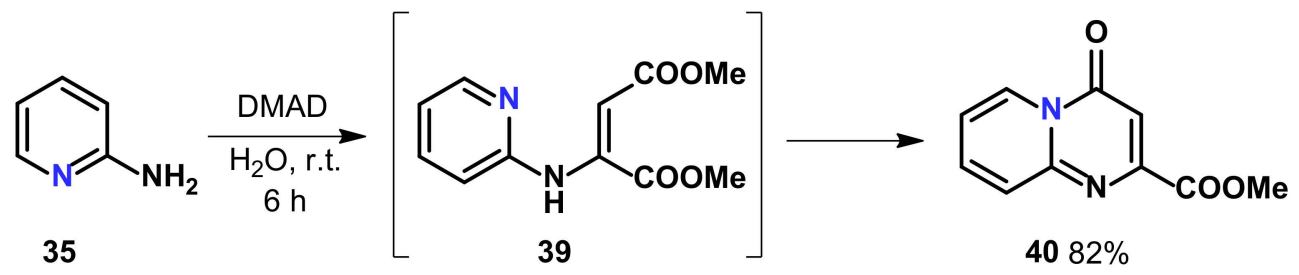

Scheme 14. Synthesis of unsubstituted $N$-bridgehead derivative 40.

A similar procedure was used by Summa et al. $[59,60]$ to synthesize 3-hydroxycontaining 9aH-pyrido[1,2-a]pyrimidine derivatives (Scheme 15). Based on the ConradLimpach procedures using DMAD as described in previous paragraphs, it is expected that the first step would involve the enamine formation of the acetylene and the amino group. However, based on their previous experiences with the synthesis of hydroxypyrimidinones, the formation of an $\mathrm{O}$-adduct intermediate was expected. This could possibly be a 2-aminopyridine- $\mathrm{N}$-oxide regarded as the tautomer of amidoxime. These derivatives are known to react with DMAD to form $O$-adducts (vinylhydroxylamines) [61-65]. The subsequent rearrangement/cyclization of $\mathbf{4 2 a} \mathbf{a} \mathbf{b}$ took place in $o$-xylene under reflux. However, the isolation of the product was not described since it was further transformed without isolation into its pivalate derivative (43a) in order to facilitate its purification. The procedure was successfully broadened to other aminopyridine derivatives as well, with $\mathrm{N}$-oxidation of the aminopyridines. It is interesting to mention that in the case of $43 \mathrm{c}$, the described final synthesis using $p$-toluenesulfonic acid $(p \mathrm{TsOH})$ as a catalyst was performed in a single step, providing the lowest yield.

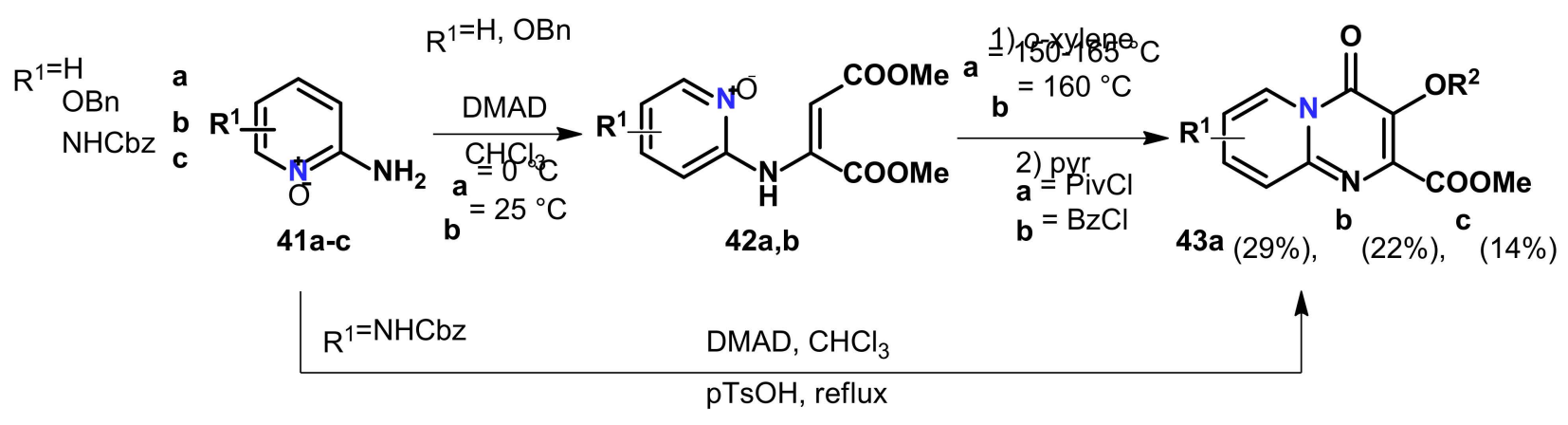

Scheme 15. Synthesis of C-3 aryl- and alkoxy-substituted derivatives 43a-c.

Furthermore, in addition to DMAD, the synthesis of the same C-3 hydroxy-functionalized compounds can be achieved through the use of a different electrophile, namely, dimethyl diacetoxyfumarate. Upon reacting with substituted 2-aminopyridines, it yields 2-hydroxypyrido[1,2-a]pyrimidin-4-on-2-carboxylic acid derivatives (45a,b, Scheme 16) [66]. The method was later applied for the synthesis of different HIV-1 integrase inhibitors [67-69].

In continuing the discussion of reactions utilizing acetylenes to yield the desired pyrido[1,2-a]pyrimidin skeleton, DMAD can also be reacted with nucleophiles derived from unique compounds. An interesting alternative method was investigated by Rees et al. using 1,2,4-triazolo[4,3-a]pyridine as the nucleophile (Scheme 17) [70]. Among other reaction routes yielding different products, DMAD can react with the $N-1$ atom 
of the triazole ring, yielding intermediate 47 a delivering 48 through a ring-opening and subsequent intramolecular ring-closure.

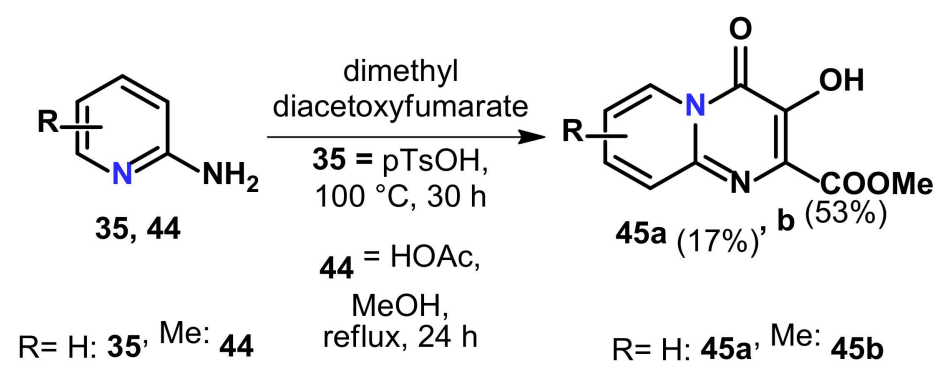

Scheme 16. Synthesis of C-3 hydroxy-substituted N-bridgehead derivatives $45 \mathbf{a}, \mathbf{b}$.

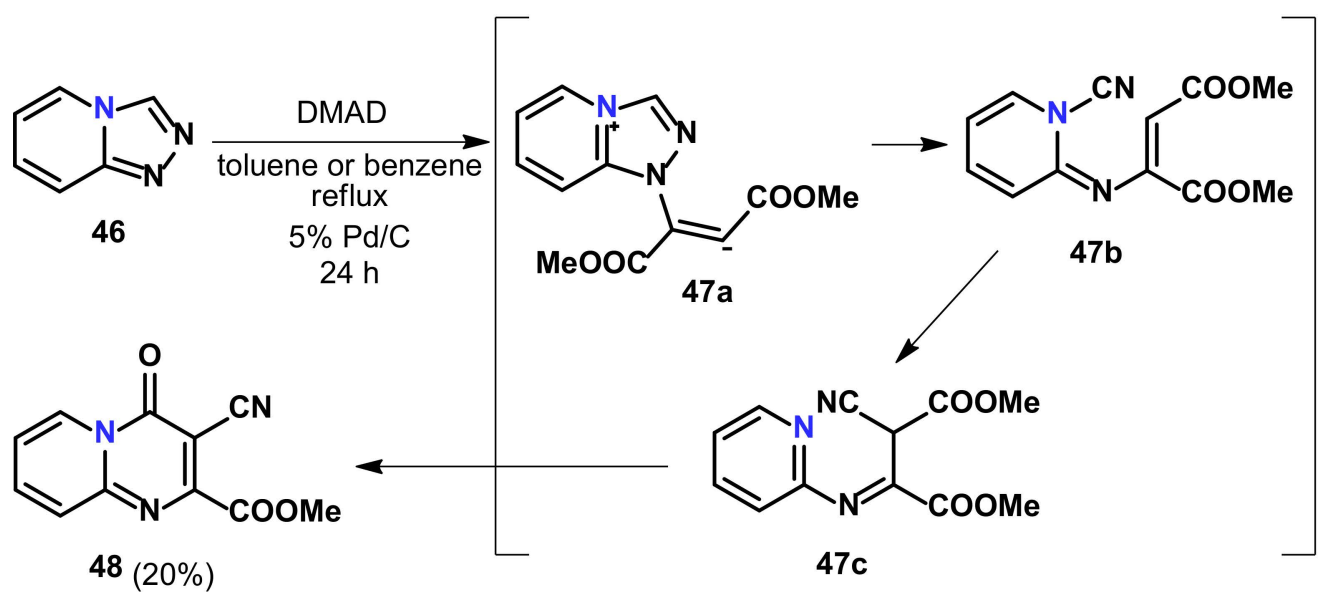

Scheme 17. Synthesis of $N$-bridgehead KYNA derivative 48 via ring-member extension.

Even though previous methods described above give possibilities for the synthesis of C-3-substituted derivatives, further functionalization can be achieved through the method reported by Ackermann et al. [71]. Starting from 2-pyridylhydrazone 49 and alkyne 50a,b, manganese-catalyzed carbonylative annulations yielding compounds 36 and 51 were carried out (Scheme 18). The method was mainly used for the synthesis of non-carboxylic derivatives; however, judging from the number of available acetylene derivatives, this reaction may provide a useful approach to synthesize new, C-3 functionalized $N$-bridgehead KYNA derivatives.

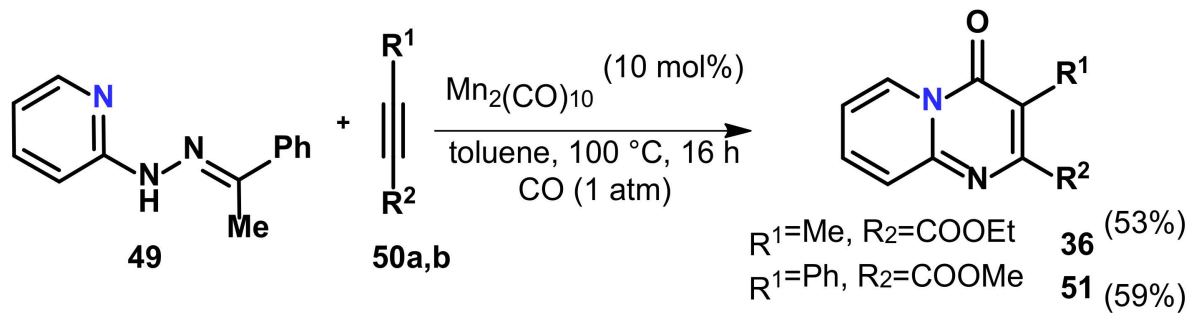

Scheme 18. Synthesis of derivatives 36 and 51 via a manganese-catalyzed reaction.

One of the first publications regarding the synthesis of the pyrido[1,2-a]-pyrimidine skeleton was published in 1969 by Sturm et al. [72]. An azide derivative, a special nucleophile, was used as starting compound upon reacting with either dimethyl fumarate $(64 \%$ product yield) or dimethyl maleate (59\% yield). The following steps were proposed for a possible mechanism. First, tautomer $52 \mathrm{~b}$ reacts with one of the electrophiles through a Diels-Alder type forming a 5-membered ring. In subsequent ring-opening and elimination of $\mathrm{N}_{2}$, enamine intermediate 39 is formed, which, after a thermally driven ring 
closure, gives $\mathbf{4 0}$ as the final product (Scheme 19). The reaction between aminopyridine and acetylenedicarboxylic acid esters resulting in the same enamine (39) and giving the same product (40) after cyclization at $140{ }^{\circ} \mathrm{C}$ was also mentioned. However, neither a synthesis description nor a literature reference were included.

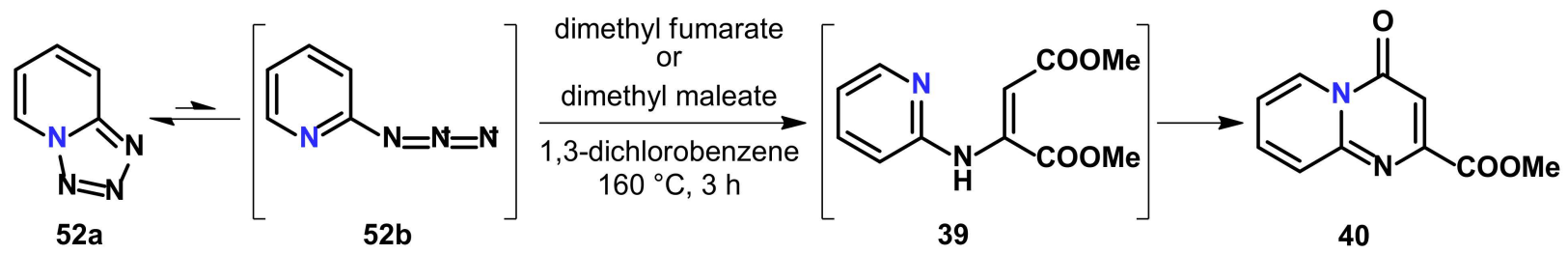

Scheme 19. Synthesis of 40 from an azide starting compound.

The use of malonic acid derivatives was also applied to synthesize derivatives bearing C-3 substitutions. However, this method requires further modifications since ring closure yields only 2-hydroxy derivative 54 that needs to be oxidized (Scheme 20) [73]. Even though the procedure itself is not as elegant as the previous ones, the use of functionalized anilines and malonic acids may yield a wide range of derivatives.

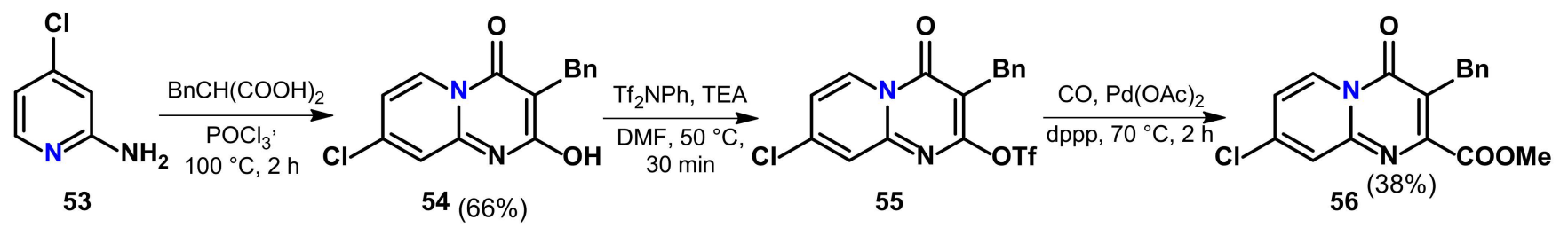

Scheme 20. Further method for the synthesis of C-3 substituted N-bridgehead derivatives.

It is worth mentioning that the formation of the pyridine-fused pyrimidine skeleton has also been observed during the pyrolysis of an isoxazoline-substituted isoquinoline (59). The research group investigated the photolysis of different isoxazoline-substituted derivatives. When the photolysis of $\mathbf{5 9}$ was changed to pyrolysis in a scale-up study, the formation of $\mathbf{6 1}$ was observed (Scheme 21) [74].<smiles>Clc1nccc2ccccc12</smiles>

57<smiles>CCOC(=O)c1[nH]oc(=O)c1C</smiles>

58<smiles>CCOC(=O)c1c(C)c(=O)on1-c1nccc2ccccc12</smiles>

59<smiles>CCOC(=O)C(C(C)=C=O)=[N+]([O-])c1nccc2ccccc12</smiles>

Scheme 21. Pyrolytic decomposition of compound 59 yielding $N$-bridgehead derivative 61 of KYNA.

Six-membered heterocycles containing more heteroatoms have reduced reactivity toward electrophiles. As a consequence, during the synthesis of KYNA skeletons with 
pyridazine, pyrimidine or pyrazine moieties, aniline starting materials may require further modifications. One such modified method applied by Mátyus et al. uses DMAD, and the accompanying aminopyridazine was substituted with electron-donating groups (EDG). However, besides electron donation, further factors may be present, as ring closure led to the formation of the desired pyrimido[1,2-b]pyridazin-2-one derivative only in the case of the hydroxy-substituted starting compound (64a). The morpholino group yielded 2-oxo-4-carboxylate analogues, similar to the chloro-substituted derivative $(\mathbf{6 4 b} \mathbf{b}, \mathbf{c}$, Scheme 22) $[75,76]$. The research group also noted this difference as an anomaly, based on previous work [77]. These pieces of information and results with electron-density calculations support the conclusion that the favored reaction would be a nucleophilic addition on the C-3 of DMAD.

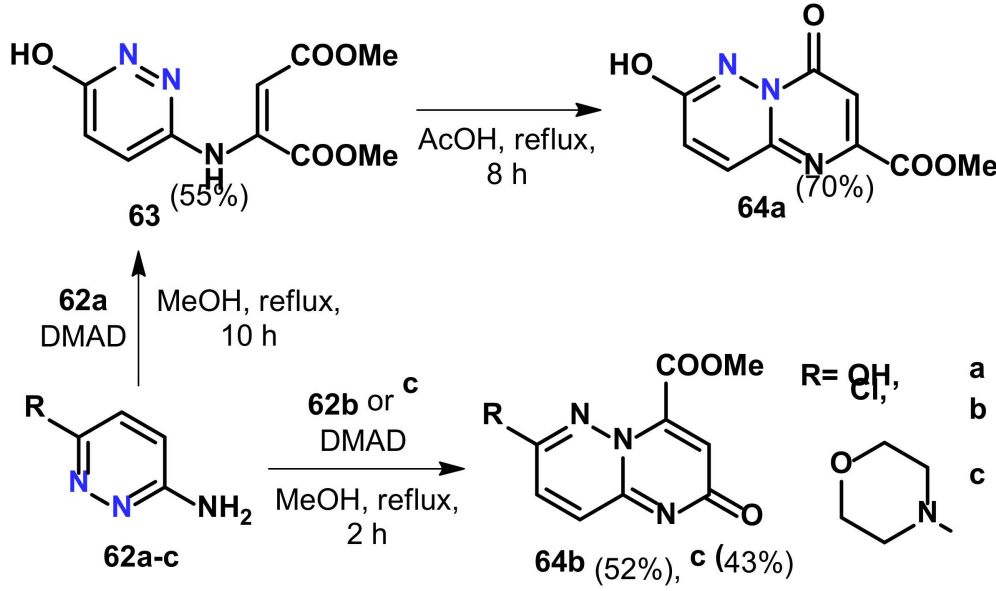

Scheme 22. Synthesis of pyrimido[1,2-b]pyridazine derivative (64a) of KYNA.

Koomen et al. [78] also used DMAD to synthesize adenosine derivatives bearing fluorescent attributes (Scheme 23). The starting 2'-deoxyadenosine compound 65 can be considered to be an imidazole-fused 6-aminopyrimidine. As previously mentioned, pyrimidine derivatives should be less reactive and thus unwilling to undergo the Michael addition; however, the imidazole ring may induce an excess of electrons of the pyrimidine ring, thus promoting the reaction.

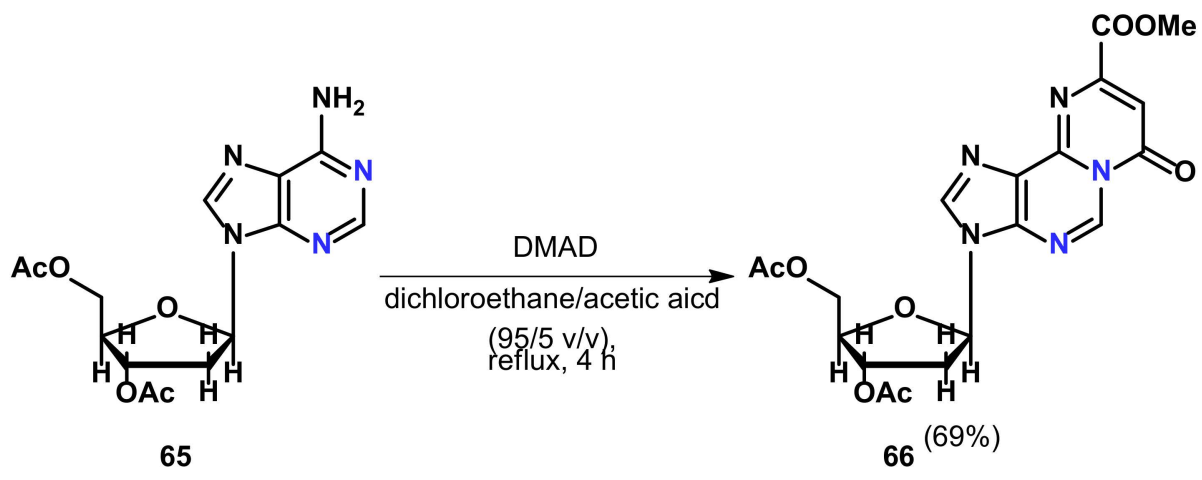

Scheme 23. Synthesis of adenosine derivative 66 .

The work of Liu et al. [79] also seems to support the hypothesis that an electrondonating substituent favors the Michael addition. The synthesis of a special tetracyclic quinoline derivative $[4(1 H)$-oxopyrimido[1,2-a]perimidine-2-carboxylate, 68$]$ was carried out starting from 2-aminoperimidine; hence, that can be considered to be 2-aminopyrimidine fused with naphthalene. Compared to the imidazole ring discussed previously, the naph- 
thalene ring has a more prominent electron-donating quality. Consequently, the reaction could be carried out in $\mathrm{MeOH}$ (Scheme 24).<smiles>NC1=Nc2cccc3cccc(c23)N1</smiles>

67

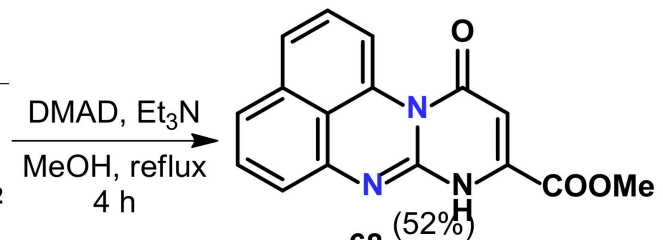

68

Scheme 24. Synthesis of perimidine derivative 68 .

The work of Jain et al. can be regarded as a further development of the study by Sturm et al. described in Scheme 19, except that it was implemented in the synthesis of bridgehead derivatives [80]. Through a different procedure, an azide intermediate was generated in both studies and was then reacted further with a fumaric acid ester (in this case, diethyl fumarate, DEF). Besides the hypothesized steps described by Sturm et al., an alternative route has also been proposed. First, the decomposition of the azide function takes place, and then a subsequent DEF attack provides an aziridine ring that opens up to give the enamine intermediates 71a-e (Scheme 25).

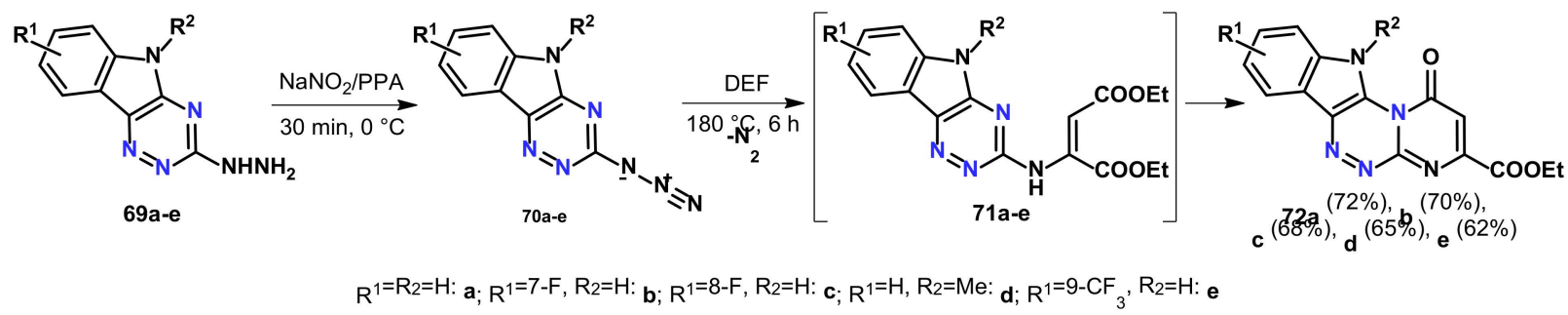

Scheme 25. Synthesis of indole-fused $N$-bridgehead derivative 72a-e from azide starting compounds.

\subsubsection{Five-Membered B-Ring Derivatives}

Since five-membered heterocyclic compounds have an excess of electrons, the modified Conrad-Limpach procedure applying DMAD or DEAD (diethyl acetylenedicarboxylate) for the intermediate formation and subsequent ring closure can be easily carried out. Both pyrrolo[2,3-b]pyridine and pyrrolo[3,2-b]pyridine ring systems (Figure 2. III) have been synthesized in a similar way. Grinev et al. used the potassium salt of 3-aminoindole2-carboxylic acid in glacial acetic acid yielding 3-aminoindole in situ that subsequently reacted with DEAD (Scheme 26) [81]. The reaction yields $\delta$-carbolines $\mathbf{7 6 a - c}$, similar to the reactions described by Guyot et al. reporting the synthesis of $\alpha$-carboline derivatives 79 (Scheme 27) [82].

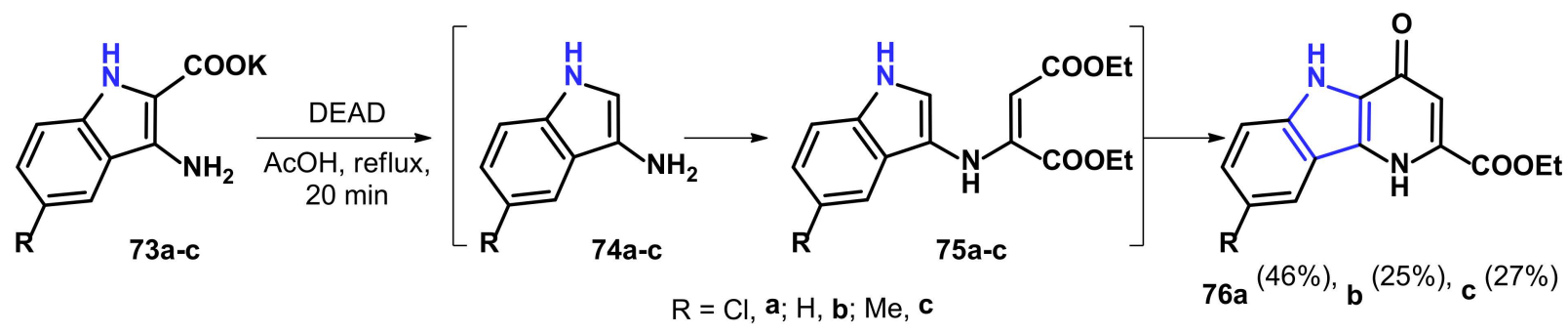

Scheme 26. Synthesis of $\delta$-carboline KYNA derivatives 76a-c. 


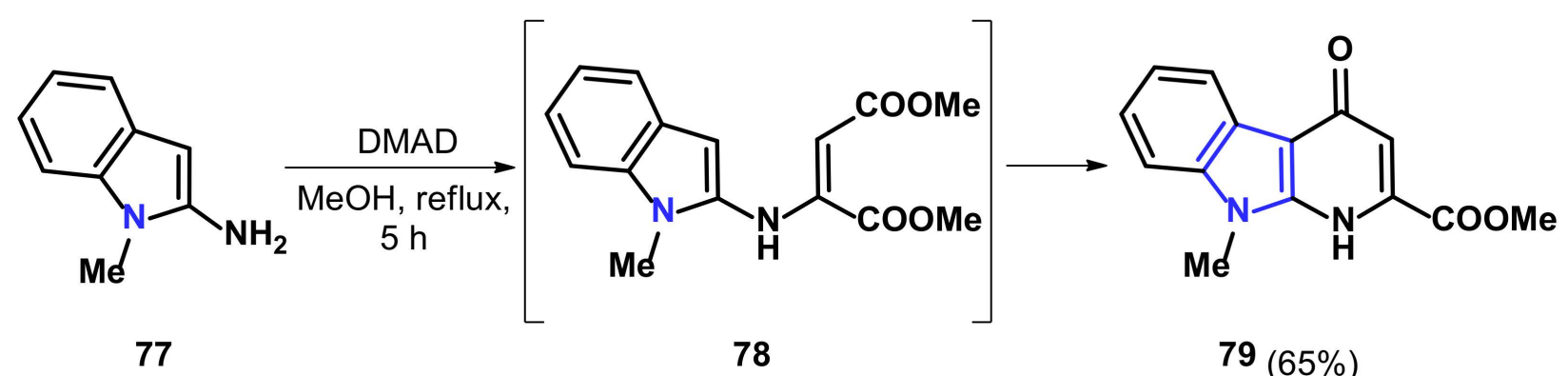

Scheme 27. Synthesis of $\alpha$-carboline KYNA derivative 79.

It is interesting to note that in both cases, likely as a consequence of the high nucleophilicity of indole, the formation of side-products was also reported. In the synthesis of $\delta$-carbolines, pentacyclic aromatic compounds appeared bearing an additional indole structure. In the case of $\alpha$-carboline derivatives, in turn, Guyot et al. used N-methyl2-aminoindole to presumably inhibit the formation of bridge-head nitrogen-containing derivatives. It was not directly specified by Guyot et al. whether it was for this reason. Nevertheless, in the following paragraphs, they described the synthesis of derivatives, where the ring closure takes place at the unsubstituted $\mathrm{N}-1$ atom.

The same Conrad-Limpach procedure can also be used for the synthesis of the pyrrolo[3,4- $b]$ pyridine skeleton. Silva et al. prepared a tetraphenylporphin (tPorphin) compound containing the pyridine-2-carboxylic acid moiety fused to one of the pyrrole rings of the porphin skeleton (82a,b, Scheme 28) [83].

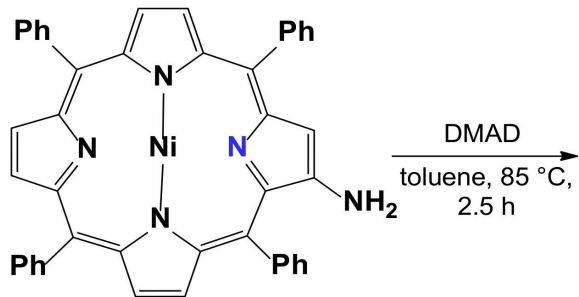

80

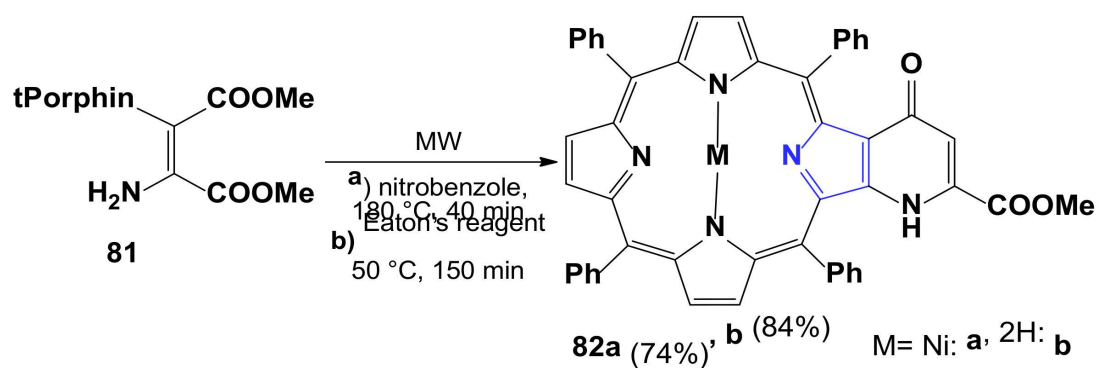

Scheme 28. Synthesis of tetraphenylporphin derivatives $\mathbf{8 2 a , b}$.

\subsection{Sulfur-Containing Ring Systems}

Both six- and five-membered derivatives (Figure 3. I and II) have been synthesized. Kitao et al. used a modified Conrad-Limpach procedure, utilizing DMAD to form enamine intermediates (84a-c); ring formation was carried out in $\mathrm{Ph}_{2} \mathrm{O}$ (Scheme 29) [84].

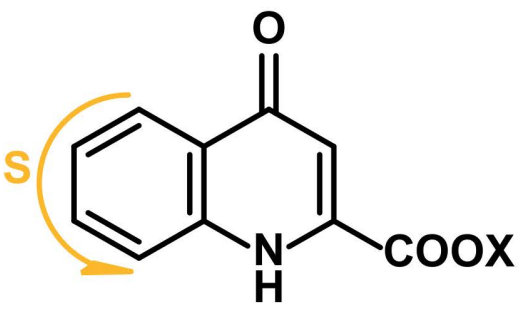

I

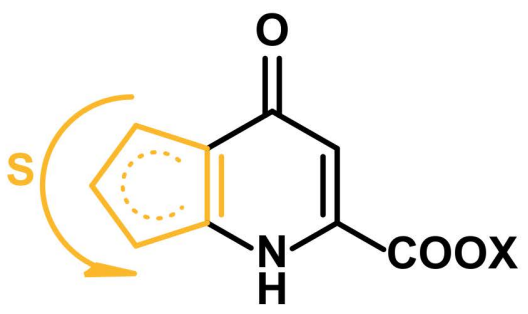

II

Figure 3. General formula for the Sulfur-containing ring system. 


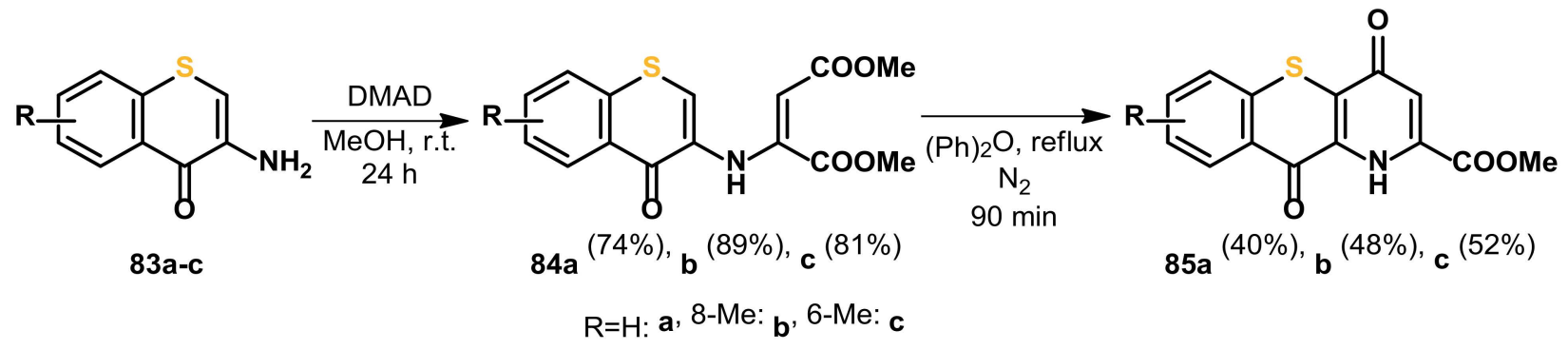

Scheme 29. Synthesis of $10 H$-thiochromeno [3,2-b]pyridine derivatives $85 a-c$.

Baron et al. fabricated a wide variety of excitatory amino acid antagonists with the six-membered B ring of KYNA changed to a five-membered sulfur-containing ring. The synthesis of these compounds is similar to that of the six-membered skeleton, utilizing DMAD or DEAD in the first step with the corresponding aminothiophenes $(\mathbf{8 6 , 8 9})$. The subsequent intramolecular ring closure was carried out in $\mathrm{Ph}_{2} \mathrm{O}$, nujol or polyphosphoric acid (Scheme 30) [85]. Unfortunately, no yields have been published for compounds $\mathbf{8 8 a}, \mathbf{b}$, 92a,b, 93a,b.<smiles>[R]OC(=O)c1cc(=O)c2cc(C#CC(=O)OCc3cccs3)sc2[nH]1</smiles>

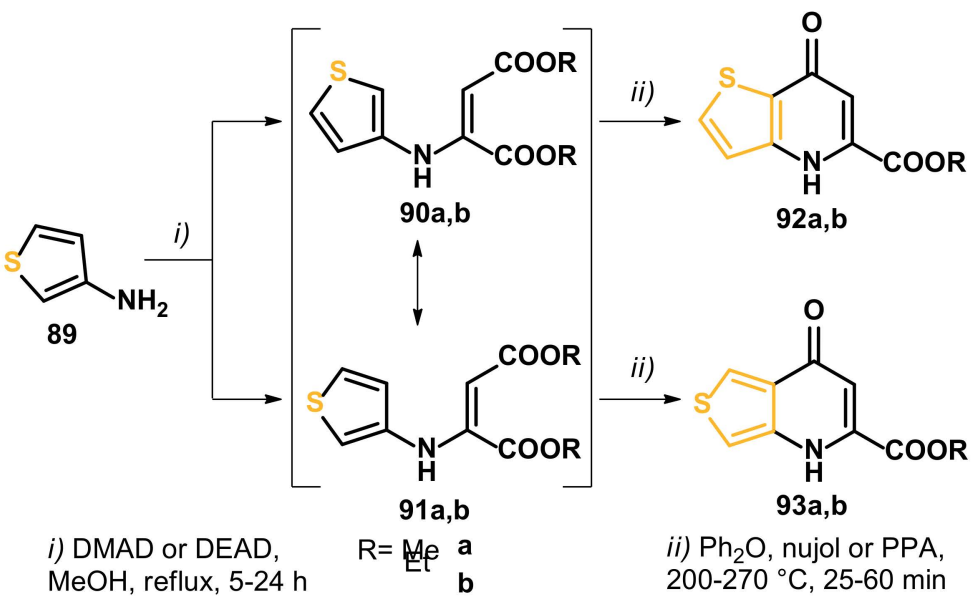

Scheme 30. Synthesis of thiophene derivatives $88 \mathbf{a}, \mathbf{b}, \mathbf{9 2 a}, \mathbf{b}$ and $\mathbf{9 3 a} \mathbf{a} \mathbf{b}$.

Although the method described in Scheme 30 has the most detailed description, it is not the only one. The synthesis of a thieno[3,2- $b$ ]pyridine system was already published earlier. Here, similar to the $\delta$-carboline derivatives [78], DEAD was used, yielding the thieno analog (95) of $\delta$-carboline derivative $\mathbf{7 6 b}$ (Scheme 31) [86].<smiles>Nc1c(C(=O)O)sc2ccccc12</smiles>

94<smiles>CC(Cl)(Br)C(=O)O</smiles><smiles>CCOC(=O)c1cc(=O)c2sc3ccccc3c2[nH]1</smiles>

$95(19 \%)$

Scheme 31. Synthesis of the thieno analog of $\delta$-carboline derivative $76 \mathbf{b}$. 
The thieno[3,4-b]pyridine skeleton was already mentioned earlier. However, in this work, the synthesis yield was not reported (Scheme 32) [87].

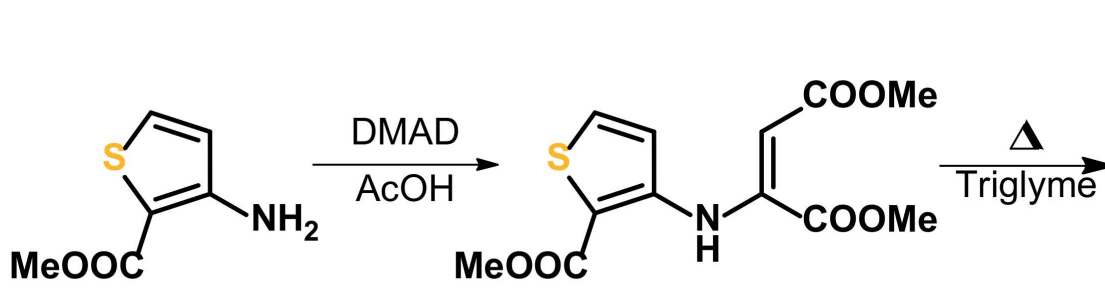

96

97<smiles>CC(=O)c1cc(=O)c2csc(C(C)=O)c2[nH]1</smiles>

98

Scheme 32. Synthesis of thieno[3,4-b]pyridine derivative 98.

\subsection{Oxygen-Containing Ring Systems}

Regarding pyrano ring systems (Figure 4. I and II), it must be emphasized that, contrary to nitrogen-bearing systems, the aromaticity of the compound is lost. Whereas the procedures described in the following paragraphs indicate that the efficiency of the synthesis is not affected, the potential biological activity may vary substantially in comparison with KYNA.<smiles>[X]C(=O)c1cc(=O)c2ccccc2[nH]1</smiles>

I<smiles>[X]C(=O)c1cc(=O)c2ccccc2[nH]1</smiles>

II

Figure 4. General formula for the Oxygen-containing ring system.

Kitao et al. based their procedure for the thiopyrano derivatives [81] on the work of Strandtmann et al. [88], who synthesized 1,5-dihydro-4,10-dioxobenzopyranopyridine-2carboxylic acid derivatives 101a-c (Scheme 33).

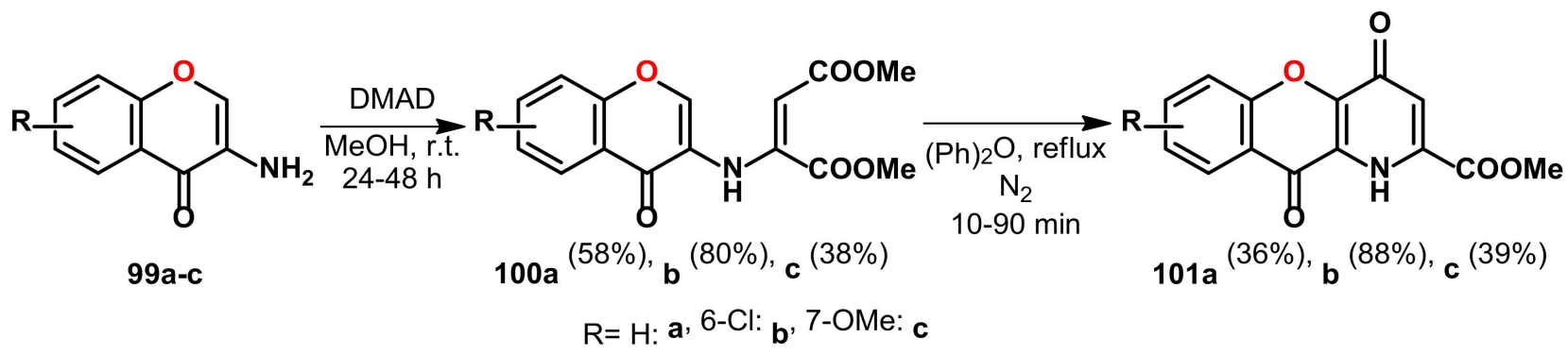

Scheme 33. Synthesis of benzopyranopyridine derivatives 101a-c.

Dorokhov et al., besides synthesizing the pyridine- and pyrimidine-fused derivatives with the use of acetophenones [31,32], also achieved the synthesis of pyranone derivatives. Pyranones 102a-c bearing the crucial active $\alpha$-methyl function, similar to the ones used for pyridine- and pyrimidine-fused derivatives synthesized previously, were reacted with diethyl oxalate in the presence of sodium ethoxide (Scheme 34) [89]. 
<smiles>[R]c1cc(N)c(C(C)=O)c(=O)o1</smiles>

$102 a-c$<smiles>[R]c1cc2[nH]c(C(=O)OCC)cc(=O)c2c(=O)o1</smiles>

$103 \mathbf{a}_{(71 \%),}$ b

$$
\mathrm{R}=\mathrm{Ph}: \mathbf{a}, 4-\mathrm{MeC}_{6} \mathrm{H}_{4}: \mathbf{b}, 4-\mathrm{ClC}_{6} \mathrm{H}_{4}: \mathbf{c}
$$

Scheme 34. Synthesis of pyrano[4,3-b]pyridine compounds 103a-c via acetophenone derivatives.

The method used by Strandtmann et al. in the synthesis of benzopyrano[2,3-b]pyridine derivatives mentioned above was extended by the research group to synthesize benzopyrano[3,4-b]pyridine derivatives (106a-c, Scheme 35) [88]. The triazol derivatives of these compounds have been patented for their possible useful application in allergic manifestations such as bronchial asthma, hay fever, etc. [90].

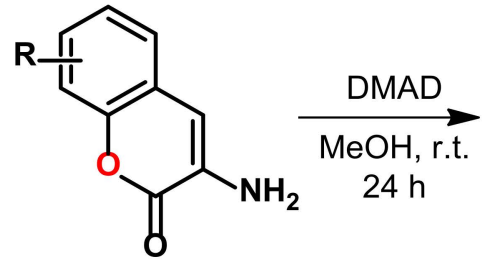

104a-c

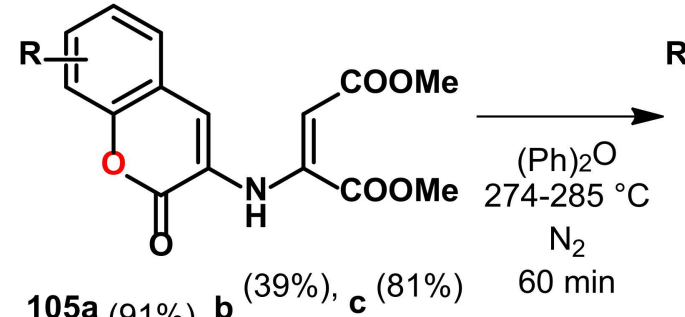<smiles>[R][X]c1cccc2c1oc(=O)c1[nH]c(C(=O)OC)cc(=O)c12</smiles>

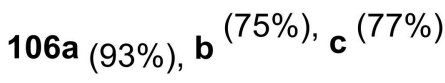

$$
\mathrm{R}=: \mathbf{a}, 6-\mathrm{OMe}: \mathbf{b}, 8-\mathrm{OMe}: \mathbf{c}
$$

Scheme 35. Synthesis of pyrano[3,4-b]pyridine derivatives 106a-c.

Regarding the furan-fused 4-oxopyridine-2-carboxylic acid derivatives, the only synthesis mentioned describes a procedure similar to that applied in the synthesis of $\delta$ carbolines reported earlier [82]. Using a potassium salt of 3-aminobenzofuran-2-carboxylic acid (107) and DMAD, compound 108 , the furan analog of $\delta$-carboline $\mathbf{7 6 b}$ could be synthesized (Scheme 36) [91].<smiles>Nc1c(C(=O)[O-])oc2ccccc12</smiles>

107

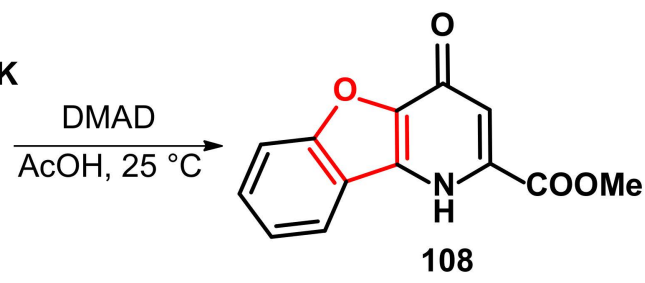

108

Scheme 36. Synthesis of $\mathbf{1 0 8}$ the furan analog of $\delta$-carboline $\mathbf{7 6 b}$.

\subsection{New Aspects on the Synthesis of KYNA Derivatives}

The aforementioned modified Conrad-Limpach procedure, applying DEAD and an aniline, has already been applied in the synthesis of KYNA [36] and several of its B-ring substituted derivatives [8-10].

The synthesis applying this kind of C-L has recently been optimized by Szatmári et al. by applying two steps: (i) after the formation of enamine 110a, column chromatography was used to purify the intermediate; (ii) $\mathrm{Ph}_{2} \mathrm{O}$ was replaced by $\mathrm{DCB}$, which has a lower boiling point $\left(180^{\circ} \mathrm{C}\right)$ allowing an easier work-up procedure (Scheme 37) [92]. 


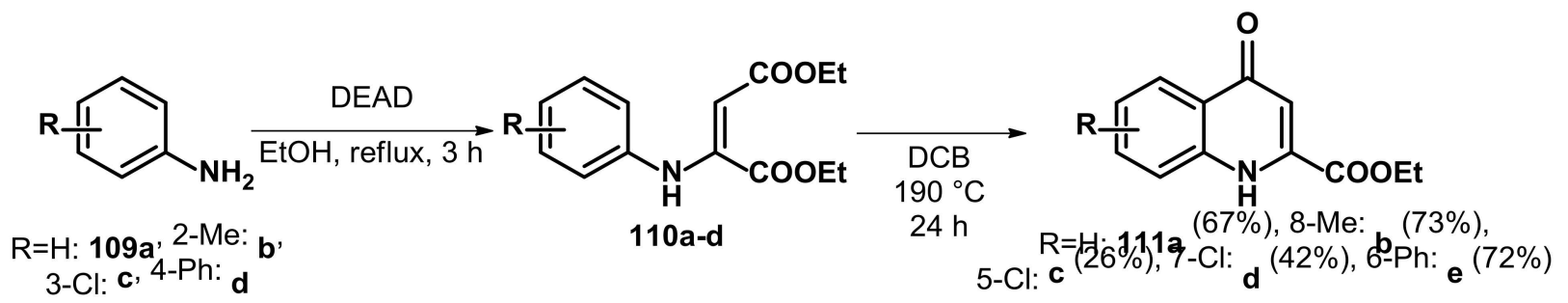

Scheme 37. Synthesis of KYNA ethyl ester.

The synthesis of the methyl ester analogs of 114a-c has already been described [93,94]; however, no yields or exact synthetic procedures were detailed. Szatmári et al. successfully carried out the synthesis of compounds 114a-c, applying the before mentioned optimizations, reaching higher yields [95]. Furthermore, based on the work of Sutherland et al. [96], $p$-TsOH as a catalyst was investigated in a one-pot version of the Conrad-Limpach procedure applying microwave irradiation (Scheme 38) [95]. The synthesis provided the appropriate hydroxy derivatives in increased yields with diminished maleimide formation, and the work-up could be carried out without time-consuming chromatography.

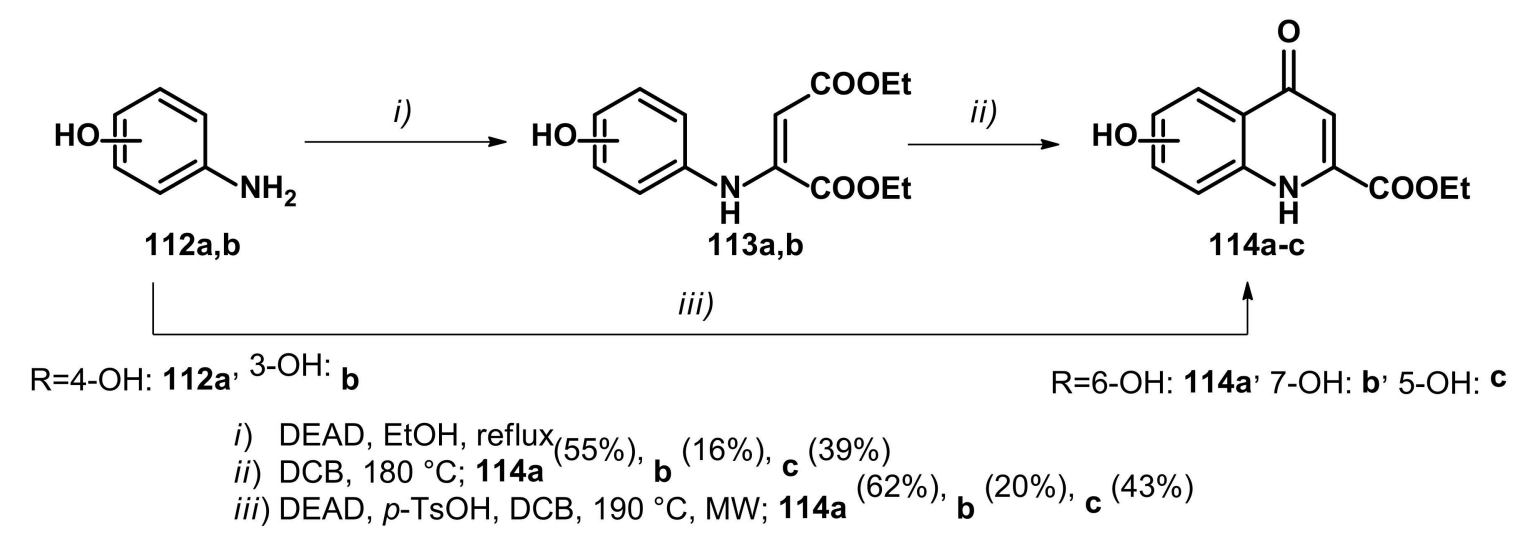

Scheme 38. Synthesis of hydroxykynurenic acid derivatives.

\section{Mannich-Type Transformations of KYNA and Its Substituted Derivatives}

\subsection{C-3 Substitutions of KYNA Derivatives}

Formally, KYNA can be considered to be a nitrogen-containing 1-naphthol derivative. Based upon their previous works with 1-naphthol and its N-containing analogs [97-100], Szatmári et al. successfully applied the ethyl ester of KYNA in the modified Mannich reaction $(m \mathrm{Mr})$ [101]. In this regard, to explore the scope and limitations of the reaction, different primary and secondary amines (acyclic and cyclic) were reacted with KYNA in the presence of formaldehyde ( $22 \%$ solution) in an optimized reaction condition of 1,4-dioxane as solvent under reflux conditions with a $5 \mathrm{~h}$ reaction time. The synthesis all yielded the C-3 aminoalkylated kynurenic acid derivatives 118-126 (Scheme 39, Table 2).<smiles>[R]C(c1c(C(=O)O)[nH]c2ccccc2c1=O)N([R])[R]</smiles>

118-126

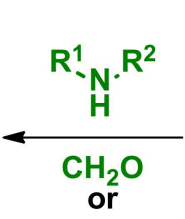

$\mathrm{PhCHO}$

$\mathrm{R}^{1=\mathrm{H}}$<smiles>[R11]c1ccc2[nH]c(C(=O)OCC)cc(=O)c2c1</smiles>

$\mathrm{R}^{1=\mathrm{H}:}$ 111a, 8-Me: $\mathbf{b}$, 5-Cl: c, 7-Cl: $\mathbf{d}$, 6-Ph: e<smiles>O=C(O)c1[nH]c2cc[R11]cc2c(=O)c1CN1CCOCC1</smiles>

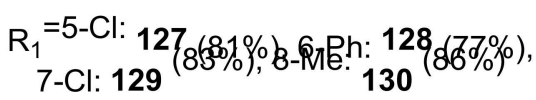

Scheme 39. Synthesis of KYNA and B-ring substituted KYNA Mannich derivatives. 
Table 2. KYNA Mannich derivatives.

\begin{tabular}{|c|c|c|c|c|}
\hline Compound \# & $\mathbf{R}^{2}$ & $\mathbf{R}^{3}$ & $\mathrm{R}^{4}$ & Yield (\%) \\
\hline 118 & $\mathrm{H}$ & 2-morpholinoethyl & $\mathrm{H}$ & 78 \\
\hline 119 & $\mathrm{H}$ & 2-(dimethylamino)ethyl & $\mathrm{Ph}$ & 74 \\
\hline 120 & $\mathrm{Me}$ & $\mathrm{Me}$ & $\mathrm{H}$ & 82 \\
\hline 121 & $\mathrm{Me}$ & $\mathrm{Bz}$ & $\mathrm{H}$ & 85 \\
\hline 122 & \multicolumn{2}{|c|}{ morpholine } & $\mathrm{H}$ & 91 \\
\hline 123 & \multicolumn{2}{|c|}{ piperidine } & $\mathrm{H}$ & 73 \\
\hline 124 & \multicolumn{2}{|c|}{$N$-methyl-piperazine } & $\mathrm{H}$ & 78 \\
\hline 125 & \multicolumn{2}{|c|}{ 1,2,3,4-tetrahydroisoquinoline } & $\mathrm{H}$ & 81 \\
\hline 126 & \multicolumn{2}{|c|}{ 6,7-dimethoxy-1,2,3,4-tetrahydroisoquinoline } & $\mathrm{H}$ & 72 \\
\hline
\end{tabular}

To test the effect of substituents at positions $5,6,7$ or 8 on the $m \mathrm{Mr}$, derivatives $\mathbf{1 1 1 b}-\mathbf{e}$ were reacted with morpholine as a representative secondary cyclic amine in the presence of formaldehyde. Reactions were carried out under the optimized reaction conditions, concluding that aryl/alkyl substituents at position 6 or 8 and the halogen at position 5 or 7 have no significant influence on the aminoalkylation at C-3 (Scheme 40, 127-130).
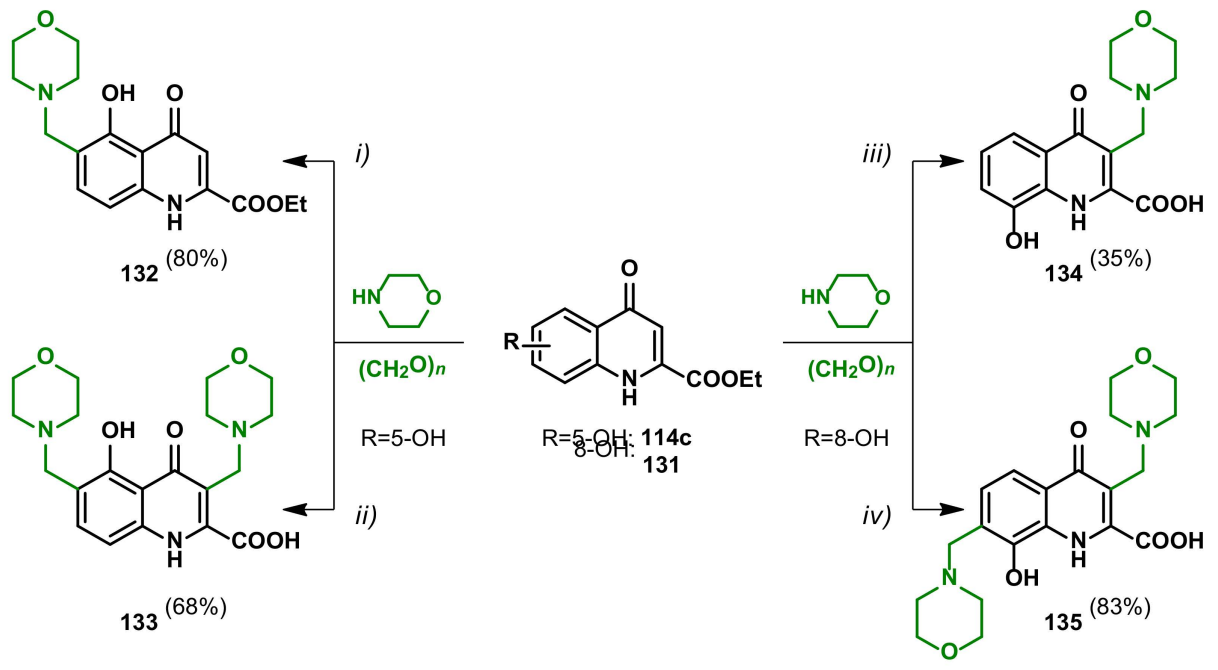

Scheme 40. Aminoalkylations of the ethyl esters of 5- and 8-hydroxykynurenic acids. (i) 114c: morpholine: $\left(\mathrm{CH}_{2} \mathrm{O}\right)_{\mathrm{n}} 1: 1: 3$; EtOH, $\mathrm{MW}, 150{ }^{\circ} \mathrm{C}, 1$ h; (ii) 114c:morpholine: $\left(\mathrm{CH}_{2} \mathrm{O}\right)_{\mathrm{n}}$ 1:3:4.6; EtOH, MW, $80{ }^{\circ} \mathrm{C}, 2$ h; (iii) 131:morpholine: $\left(\mathrm{CH}_{2} \mathrm{O}\right)_{\mathrm{n}}$ 1:1:3; dioxane, $\mathrm{MW}, 150{ }^{\circ} \mathrm{C}, 2 \mathrm{~h}$; (iv) 131:morpholine: $\left(\mathrm{CH}_{2} \mathrm{O}\right)_{\mathrm{n}}$ 1:3:4.6; toluene, $\mathrm{MW}, 80^{\circ} \mathrm{C}, 1 \mathrm{~h}$.

\subsection{Aminoalkylations of Hydroxy-KYNA Derivatives}

Regarding the 1-naphthol analogy of KYNA, the B-ring substituted derivatives show possibilities for further fascinating $m \mathrm{Mr}$ transformations. Compounds 114c, 131 through their analogy with 1-naphthol and 114a,b through their 2-naphthol analogy (Figure 5), offer new possible reaction routes for the aminoalkylation.<smiles>CCOC(=O)c1cc(=O)c2c(O)cccc2[nH]1</smiles>

$114 \mathrm{c}$<smiles>CCOC(=O)c1cc(=O)c2cccc(O)c2[nH]1</smiles>

131<smiles>CCOC(=O)c1cc(=O)c2ccc(O)cc2[nH]1</smiles>

114a<smiles>CCOC(=O)c1cc(=O)c2cc(O)ccc2[nH]1</smiles>

114b

Figure 5. Structures of hydroxy-KYNA derivatives. 


\subsubsection{Derivatives with Structural Similarities to 1-Napthol}

Hydroxylated KYNA derivatives bearing the secondary hydroxy function at position 5 or 8 show a second 1-napthol similarity. In this case, the aminoalkylations can be expected to first undergo it in position 6 or 7, respectively, as these positions can both be regarded as the C-2 and, consequently, the most reactive position of a 1-napthol skeleton, as well as the sterically-less hindered position of the KYNA skeleton. However, this substitution route was observed by Szatmári et al. only in the case of compound 114c, the reactions first yielding 132, and subsequently 133 . The morpholinomethylation in the case of the 8-hydroxy derivative (131) first took place at C-3, yielding 134 and only after that at C-7 (Scheme 40, 135) [95].

In both cases, DFT calculations were carried out to support the observed results, showing that the reason behind the sluggish and irregular reactivity of $\mathbf{1 3 1}$ might be due to its low HOMO energy level.

\subsubsection{Derivatives with Structural Similarities to 2-Napthol}

In the case of the 6- and 7-hydroxykynurenic acids $(\mathbf{1 1 4 a , b})$, a similarity between the skeleton and 2-naphthol can be observed, implicating that the aminoalkylations may take place in position 5 or 7 , respectively. After performing the reactions, it has been observed that only compound 114b shows the expected reactivity with the morpholinomethyl function first forming at position C-8 (138) and subsequently in position C-3 (Scheme 41, 139). In the case of compound 114a, the reaction first led to the formation of the C-3 substituted derivative and later to the formation of the disubstituted derivative (136 and 137). This unexpected reactivity was later investigated by DFT calculation disclosing $\mathrm{HOMO}$ delocalization and local NBO charges for the corresponding anion pairs theorized to form during the reaction. These calculations were in line with the experimental results implying that in the case of 114a, despite the similarity to 2-naphthol, the additional functional groups and heteroatom in the ring-system may override the reactivity expected from the sterically-less hindered 2-naphthol skeleton, resulting in the formation of $\mathbf{1 3 6}$ as a primary product [95].
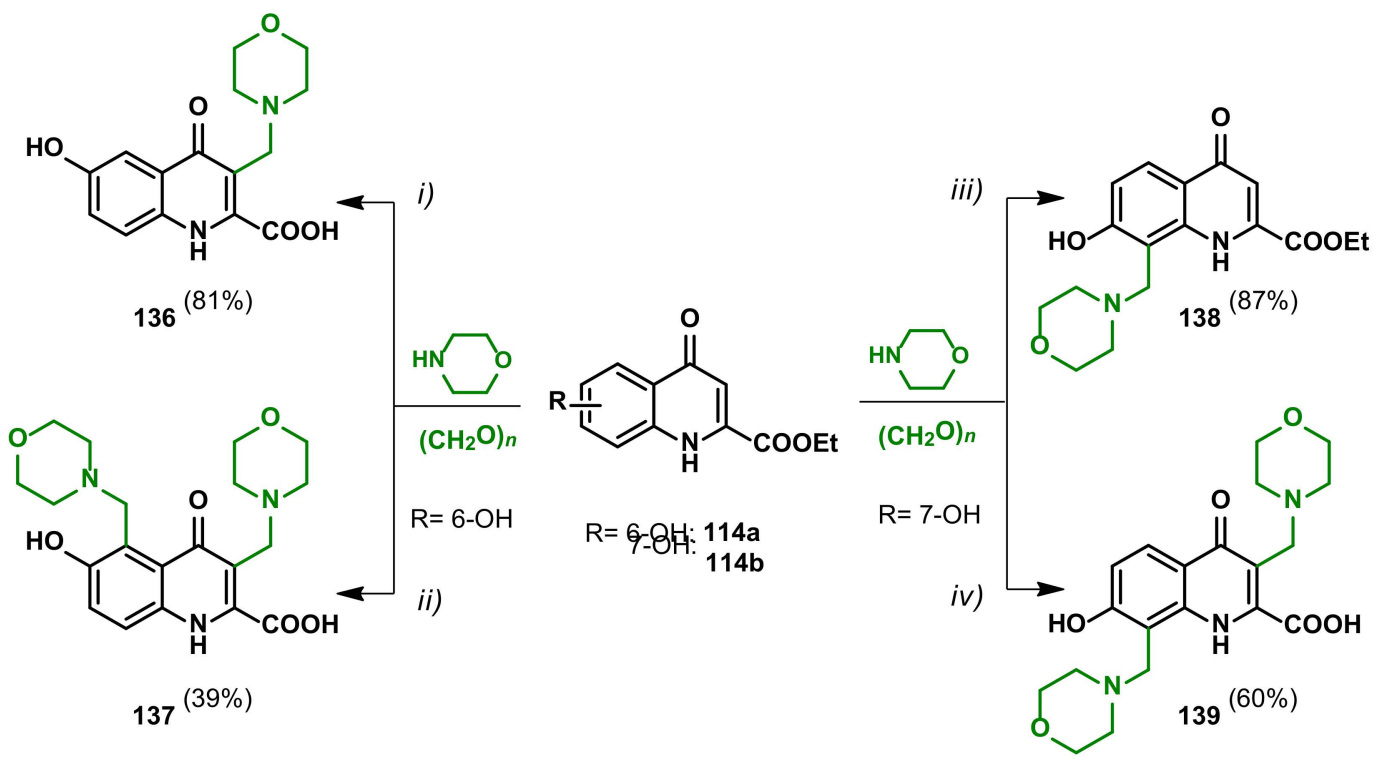

Scheme 41. Morpholinomethylations of the ethyl esters of 6- and 7-hydroxykynurenic acids. (i) 114a:morpholine: $\left(\mathrm{CH}_{2} \mathrm{O}\right)_{\mathrm{n}}$ 1:3:4.6; EtOH, MW, $80{ }^{\circ} \mathrm{C}, 30 \mathrm{~min}$; (ii) 114a:morpholine: $\left(\mathrm{CH}_{2} \mathrm{O}\right)_{\mathrm{n}}$ 1:3:4.6; EtOH, MW, $80{ }^{\circ} \mathrm{C}, 2 \mathrm{~h}$; (iii) 114b: morpholine: $\left(\mathrm{CH}_{2} \mathrm{O}\right)_{\mathrm{n}}$ 1:1:3; EtOH, MW, $80{ }^{\circ} \mathrm{C}, 1.5 \mathrm{~h}$; (iv) 114b:morpholine: $\left(\mathrm{CH}_{2} \mathrm{O}\right)_{\mathrm{n}}$ 1:2:4; EtOH, reflux, $56 \mathrm{~h}$. 


\section{Conclusions}

Kynurenic acid derivatives with a modified B-ring skeleton represent an interesting alternative for the synthesis of new KYNA analogs. Most of the compounds discussed have already been synthesized with the aim of biological use, such as antiviral, antimicrobial, antiallergic or antitumor effects; however, only a fraction of them have been tested for KYNA-like effects. The primary aim of this review was to summarize the procedures used for the synthesis of KYNA derivatives. These syntheses, combined with the second aim of the review-transformations, facilitating blood-brain-barrier penetration-may pave the way for future pharmaceutical chemistry concerning KYNA derivatives.

Summarizing the procedures used for the synthesis of B-ring modified KYNA derivatives, they build upon the reaction between a nucleophile (heteroatom-containing aniline/ five-membered aromatic compound with an amine function) and an electrophile [ $\beta$-keto ester/dicarboxylic alkyne (DEAD or DMAD)]. Based on the electrophiles, the reactions can be categorized as Conrad-Limpach (using $\beta$-keto esters) and modified Conrad-Limpach (using DEAD or DMAD) procedures.

While the unmodified procedure may give way for C-3 substitution of the KYNA skeleton without further transformations needed, the modified Conrad-Limpach procedure, compared to the prior, has the advantage of a cheaper electrophile and, combined with the recent optimization steps or one-pot reaction set-up may provide a more costefficient synthesis.

As KYNA is mainly known in the literature for its neuroprotective effect, the modified Mannich reaction, resulting in derivatives bearing one or more tertiary nitrogen and thus having better blood-brain-barrier penetration, rises as a possible further transformation. As KYNA and some of its derivatives can easily undergo this reaction, it is safe to hypothesize that the B-ring modified derivatives that can be fabricated with the procedures summarized in this review can also undergo the reaction and may provide potentially neuroprotective compounds.

Author Contributions: Conceptualization, I.S.; investigation, B.L.; writing-original draft preparation, B.L.; writing-review and editing, I.S. All authors have read and agreed to the published version of the manuscript.

Funding: This research received no external funding.

Acknowledgments: The authors' thanks are due to the Hungarian Research Foundation (OTKA No. K-138871); the Ministry of National Economy, National Research Development and Innovation Office [GINOP-2.3.2-15-2016-00034]; the Ministry of Human Capacities, Hungary grant, TKP-2020 and to the Gedeon Richter Plc. Centenarial Foundation.

Conflicts of Interest: The authors declare no conflict of interest.

$\begin{array}{ll}\text { Abbreviations } & \\ & \\ \text { Acetonitrile } & \mathrm{MeCN} \\ \text { Blood-brain barrier } & \mathrm{BBB} \\ \text { 1,2-Dichlorobenzene } & \mathrm{DCB} \\ \text { Diethylacetylene dicarboxylate } & \mathrm{DEAD} \\ \text { Diethyl fumarate } & \mathrm{DEF} \\ \text { N,N'-Diisopropylcarbodiimide } & \mathrm{DIC} \\ \text { Dimethylacetylene dicarboxylate } & \mathrm{DMAD} \\ \text { N,N-Dimethylformamide } & \mathrm{DMF} \\ \text { Diphenyl ether } & \mathrm{Ph} 2 \mathrm{O} \\ \text { 1,3-Bis(diphenylphosphino)propane } & \mathrm{dppp} \\ \text { Electron-donating groups } & \mathrm{EDG} \\ \text { 1-Hydroxybenzotriazole hydrate } & \mathrm{HOBt} \\ \text { Nicotinamide adenine dinucleotide } & \mathrm{NAD}\end{array}$




$\begin{array}{ll}\text { Modified Mannich reaction } & \text { mMr } \\ \text { Polyphosphoric acid } & \text { PPA } \\ \text { Tetraphenylporphin } & \text { tPorphin } \\ \text { TNF-stimulated gene } 6 \text { protein } & \text { TSG-6 } \\ \text { p-Toluenesulfonic acid } & \text { pTsOH } \\ \text { Triethylamine } & \text { TEA } \\ \text { Tryptophan } & \text { TRP } \\ \text { Tumor necrosis factor alpha } & \text { TNF- } \alpha\end{array}$

\section{References}

1. Rózsa, E.; Robotka, H.; Vécsei, L.; Toldi, J. The Janus-face kynurenic acid. J. Neural Transm. 2008, 115, 1087-1091. [CrossRef]

2. Stone, T.W. Kynurenic acid antagonists and kynurenine pathway inhibitors. Expert Opin. Inv. Drug. 2001, 10, 633-645. [CrossRef] [PubMed]

3. Németh, H.; Toldi, J.; Vécsei, L. Role of kynurenines in the central and peripheral nervous systems. Curr. Neurovasc. Res. 2005, 2, 249-260. [CrossRef] [PubMed]

4. Németh, H.; Toldi, J.; Vécsei, L. Kynurenines, Parkinson's disease and other neurodegenerative disorders: Preclinical and clinical studies. J. Neural Transm. Supp. 2006, 70, 285-304.

5. Sas, K.; Robotka, H.; Toldi, J.; Vécsei, L. Mitochondria, metabolic disturbances, oxidative stress and the kynurenine system, with focus on neurodegenerative disorders. J. Neurol. Sci. 2007, 257, 221-239. [CrossRef] [PubMed]

6. Gigler, G.; Szénási, G.; Simó, A.; Lévay, G.; Hársing, L.G., Jr.; Sas, K.; Vécsei, L.; Toldi, J. Neuroprotective effect of L-kynurenine sulfate administered before focal cerebral ischemia in mice and global cerebral ischemia in gerbils. Eur. J. Pharmacol. 2007, 564, 116-122. [CrossRef] [PubMed]

7. Luchowska, E.; Luchowski, P.; Sarnowska, A.; Wielosz, M.; Turski, W.A.; Urbańska, E.M. Endogenous level of kynurenic acid and activities of kynurenine aminotransferases following transient global ischemia in the gerbil hippocampus. Pol. J. Pharmacol. 2003, 55, 443-447. [PubMed]

8. Harrison, B.L.; Baron, B.M.; Cousino, D.M.; McDonald, I.A. 4-[(Carboxymethyl)oxy]- and 4-[(carboxymethyl)amino]-5,7dichloroquinoline-2-carboxylic acid: New antagonists of the strychnine-insensitive glycine binding site on the N-methylD-aspartate (NMDA) receptor complex. J. Med. Chem. 1990, 33, 3130-3132. [CrossRef] [PubMed]

9. Edmont, D.; Rocher, R.; Plisson, C.; Chenault, J. Synthesis and evaluation of quinoline carboxyguanidines as antidiabetic agents. Bioorg. Med. Chem. Lett. 2000, 16, 1831-1834. [CrossRef]

10. Bonina, F.P.; Arenare, L.; Ippolito, R.; Boatto, G.; Battaglia, G.; Bruno, V.; De Caprariis, P. Synthesis, pharmacokinetics and anticonvulsant activity of 7-chlorokynurenic acid prodrugs. Int. J. Pharm. 2000, 202, 79-88. [CrossRef]

11. Manfredini, S.; Pavan, B.; Vertuani, S.; Scaglianti, M.; Compagnone, D.; Biondi, C.; Scatturin, A.; Tanganelli, S.; Ferraro, L.; Prasad, P.; et al. Design, synthesis and activity of ascorbic acid prodrugs of nipecotic, kynurenic and diclophenamic acids, liable to increase neurotropic activity. J. Med. Chem. 2002, 45, 559-562. [CrossRef] [PubMed]

12. Manfredini, S.; Vertuani, S.; Pavan, B.; Vitali, F.; Scaglianti, M.; Bortolotti, F.; Biondi, C.; Scatturin, A.; Prasad, P.; Dalpiaz, A. Design, synthesis and in vitro evaluation on HRPE cells of ascorbic and 6-bromoascorbic acid conjugates with neuroactive molecules. Bioorgan. Med. Chem. 2004, 12, 5453-5463. [CrossRef]

13. Yielding, K.L.; Nichols, A.C. Anticonvulsant activity of antagonists for the NMDA-associated glycine binding site. Mol. Chem. Neuropathol. 1993, 19, 269-282.

14. Stone, T.W. Inhibitors of the kynurenine pathway. Eur. J. Med. Chem. 2000, 35, 179-186. [CrossRef]

15. Nichols, A.C.; Yielding, K.L. Anticonvulsant activity of 4-urea-5,7-dichlorokynurenic acid derivatives that are antagonists at the NMDA-associated glycine binding site. Mol. Chem. Neuropathol. 1998, 35, 1-12. [CrossRef] [PubMed]

16. Füvesi, J.; Somlai, C.; Németh, H.; Varga, H.; Kis, Z.; Farkas, T.; Károly, N.; Dobszay, M.; Penke, Z.; Penke, B.; et al. Comparative study on the effects of kynurenic acid and glucosamine-kynurenic acid. Pharmacol. Biochem. Behav. 2004, 77, 95-102. [CrossRef]

17. Zhang, L.; Sun, F.; Li, Y.; Sun, X.; Liu, X.; Huang, Y.; Zhang, L.H.; Ye, X.S.; Xiao, J. Rapid Synthesis of Iminosugar Derivatives for Cell-Based In Situ Screening: Discovery of "Hit" Compounds with Anticancer Activity. ChemMedChem 2007, 2, $1594-1597$. [CrossRef]

18. Brik, A.; Lin, Y.C.; Elder, J.; Wong, C.H. A quick diversity-oriented amide forming reaction coupled with in situ screening as an approach to identify optimal p-subsite residues of HIV-1 protease inhibitors. Chem. Biol. 2002, 9, 891-896. [CrossRef]

19. Tossi, A.; Benedetti, F.; Norbedo, S.; Skrbec, D.; Berti, F.; Romeo, D. Small hydroxyethylene-based peptidomimetics inhibiting both HIV-1 and C. albicans aspartic proteases. Bioorg. Med. Chem. 2003, 11, 4719-4727. [CrossRef] [PubMed]

20. Knyihár-Csillik, E.; Mihály, A.; Krisztin-Péva, B.; Robotka, H.; Szatmári, I.; Fülöp, F.; Toldi, J.; Csillik, B.; Vécsei, L. The kynurenate analog SZR-72 prevents the nitroglycerol-induced increase of c-fos immunoreactivity in the rat caudal trigeminal nucleus: Comparative studies of the effects of SZR-72 and kynurenic acid. Neurosci. Res. 2008, 61, 429-432. [CrossRef] [PubMed]

21. Fülöp, F.; Szatmári, I.; Vámos, E.; Zádori, D.; Toldi, J.; Vécsei, L. Syntheses, transformations and pharmaceutical applications of kynurenic acid derivatives. Curr. Med. Chem. 2009, 16, 4828-4842. [CrossRef]

22. Sako, M. Category 2, Hetarenes and Related Ring Systems; Yamamoto, Y., Shinkai, I., Eds.; Product Class. 19: Pyridopyrimidines; Thieme Verlagsgruppe: Stuttgart, Germany; New York, NY, USA; New Delhi, India, 2004; pp. 1155-1267. 
23. Conrad, M.; Limpach, L. Synthesen von Chinolinderivaten mittelst Acetessigester. Ber. Dtsch. Chem. Ges. 1887, $20,944-948$. [CrossRef]

24. Conrad, M.; Limpach, L. Ueber das $\gamma$-Oxychinaldin und dessen Derivate. Ber. Dtsch. Chem. Ges. 1887, 20, 948-959. [CrossRef]

25. Hauser, C.R.; Reynolds, G.A. Reactions of $\beta$-keto esters with aromatic amines. Synthesis of 2-and-4-hydroxyquinoline derivatives. J. Am. Chem. Soc. 1948, 70, 2402-2404. [CrossRef]

26. Goldberg, A.A.; Theobald, R.S.; Williamson, W. Derivatives of 2-alkoxy-8-amino-1:5-naphthyridines. J. Chem. Soc. 1954, $2357-2361$. [CrossRef]

27. Abe, S.; Haneda, T.; Hata, K.; Inoue, S.; Matsukura, M.; Nakamoto, K.; Tanaka, K.; Tsukada, I.; Ueda, N.; Watanabe, N. Novel Antifungal Agent Comprising Heterocyclic Compound. Patent WO2005033079A1, 14 April 2005.

28. Carpenter, J.; Broekema, M.; Feng, J.; Liu, C.; Wang, W.; Wang, Y. Alkene Compounds as Farnesoid X Receptor Modulators. Patent WO2019089670A1, 9 May 2019.

29. Abe, S.; Haneda, T.; Inoue, S.; Matsukura, M.; Nakamoto, K.; Sagane, K.; Tanaka, K.; Tsukada, I.; Ueda, N. Novel Antimalaria Agent Containing Heterocyclic Compound. Patent WO2006016548A1, 16 February 2006.

30. Feng, J.; Liu, C.; Huang, Y. Alkene Spirocyclic Compounds as Farnesoid X Receptor Modulators. Patent WO2019089665A1, 9 May 2019.

31. Vasil'ev, L.S.; Surzhikov, F.E.; Baranin, S.V.; Dorokhov, V.A. Trifluoromethyl-substituted 1,6-naphthyridines and pyrido[4,3d]pyrimidines. Russ. Chem Bull. 2013, 62, 1255-1261. [CrossRef]

32. Vasil'ev, L.S.; Surzhikov, F.E.; Azarevich, O.G.; Bogdanov, V.S.; Dorokhov, V.A. Synthesis of 4-hydroxy- and 3-aryl-4-amino2-trifluoromethylpyridines. Russ. Chem. Bull. 1996, 45, 2574-2577. [CrossRef]

33. Andrews, M.D.; Bagal, S.K.; Gibson, K.R.; Omoto, K.; Ryckmans, T.; Skerratt, S.E.; Stupple, P.A. Pyrrolo[2,3-d]pyrimidine Derivatives as Inhibitors of Tropomyosin-Related Kinases. Patent WO2012137089A1, 11 October 2012.

34. Andrews, M.D.; Bagal, S.K.; Gibson, K.R.; Omoto, K.; Ryckmans, T.; Skerratt, S.E.; Stupple, P.A. Pyrrolo[2,3-d]pyrimidine Tropomysin-Related Kinase Inhibitors. Patent US8846698B2, 30 September 2014.

35. Hauser, C.R.; Weiss, M.J. Cyclization Of 2-Aminopyridine Derivatives To Form 1,8-Naphthyridines. J. Org. Chem. 1949, 14, 453-459. [CrossRef]

36. Zhou, Y.; Li, W.; Liu, Y.; Zeng, L.; Su, W.; Zhou, M. Substituent effect of ancillary ligands on the luminescence of bis [4,6-(difluorophenyl)-pyridinato-N,C2']iridium(III) complexes. Dalton Trans. 2012, 31, 9373-9381. [CrossRef]

37. Carboni, S.; Da Settimo, A.; Bertini, D.; Ferrarini, P.L.; Livi, O.; Mori, C.; Tonetti, I. Gazz. Chim. Ital. 1972, 102, $253-264$.

38. Ferrand, Y.; Kendhale, A.M.; Garric, J.; Kauffmann, B.; Huc, I. Parallel and antiparallel triple helices of naphthyridine oligoamides. Angew. Chem. Int. Ed. 2010, 49, 1778-1781. [CrossRef] [PubMed]

39. Mateus, P.; Chandramouli, N.; Mackereth, C.D.; Kauffmann, B.; Ferrand, Y.; Huc, I. Allosteric recognition of homomeric and heteromeric pairs of monosaccharides by a foldamer capsule. Angew. Chem. Int. Ed. 2020, 59, 5797-5805. [CrossRef] [PubMed]

40. Gole, B.; Kauffmann, B.; Maurizot, V.; Huc, I.; Ferrand, Y. Light-controlled conformational switch of an aromatic oligoamide foldamer. Angew. Chem. Int. Ed. 2019, 58, 8063-8067. [CrossRef] [PubMed]

41. Wang, X.; Gan, Q.; Wicher, B.; Ferrand, Y.; Huc, I. Directional threading and sliding of a dissymmetrical foldamer helix on dissymmetrical axles. Angew. Chem. Int. Ed. 2019, 58, 4205-4209. [CrossRef]

42. Saha, S.; Kauffmann, B.; Ferrand, Y.; Huc, I. Selective encapsulation of disaccharide xylobiose by an aromatic foldamer helical capsule. Angew. Chem. Int. Ed. 2018, 57, 13542-13546. [CrossRef] [PubMed]

43. Suzuki, N.; Kato, M.; Dohmori, R. [Synthesis of antimicrobial agents. II. Synthesis of 1,8-naphthyridine derivatives and their activities against Trichomonas vaginalis (author's transl)]. Yakugaku Zasshi. 1979, 99, 155-164. [CrossRef]

44. Srinivasan, A.; Broom, A.D. Pyridopyrimidines. 10. Nucleophilic substitutions in the pyrido[3,2-d]pyrimidine series. J. Org. Chem. 1979, 44, 435-440. [CrossRef]

45. Rosowsky, A.; Forsch, R.A.; Queener, S.F. 2,4-Diaminopyrido[3,2-d]pyrimidine Inhibitors of Dihydrofolate Reductase from Pneumocystis carinii and Toxoplasma gondii. J. Med. Chem. 1995, 38, 2615-2620. [CrossRef]

46. Desforges, G.; Gaillard, P.; Montagne, C.; Pomel, V.; Quattropani, A. 4-Morpholino-pyrido[3,2-d]pyrimidines. Patent WO2010037765A2, 8 April 2010.

47. Shim, J.L.; Niess, R.; Broom, A.D. Acylation of some 6-aminouracil derivatives. J. Org. Chem. 1972, 37, 578-581. [CrossRef]

48. Ogura, H.; Sakaguchi, M. A novel synthesis of 5-oxo- and 7-oxo-pyrido[2,3-d]pyrimidines. Chem. Lett. 1972, 1, 657-658. [CrossRef]

49. Komkov, A.V.; Dorokhov, V.A. Simple synthesis of alkyl 5-oxo-5, 8-dihydropyrido [2, 3-d] pyrimidine-7-carboxylates from 5-acetyl-4-aminopyrimidines. Russ. Chem Bull. 2002, 51, 1875-1878. [CrossRef]

50. Cassis, R.; Tapia, R.; Valderrama, A. Synthesis of $4(1 \mathrm{H})$-quinolones by thermolysis of arylaminomethylene Meldrum's acid derivatives. Synth. Commun. 1985, 15, 125-133. [CrossRef]

51. Jadhav, S.B.; Fatema, S.; Patil, R.B.; Sangshetti, J.N.; Farooqui, M. Pyrido[1,2-a]pyrimidin-4-ones: Ligand-based Design, Synthesis, and Evaluation as an Anti-inflammatory Agent. J. Heterocycl. Chem. 2017, 54, 3299-3313. [CrossRef]

52. Yang, Y.; Shu, W.-M.; Yu, S.-B.; Ni, F.; Gao, M.; Wu, A.-X. Auto-tandem catalysis: Synthesis of 4H-pyrido[1,2-a]pyrimidin-4-ones via copper-catalyzed aza-Michael addition-aerobic dehydrogenation-intramolecular amidation. Chem. Commun. 2013, 49, 1729-1731. [CrossRef] [PubMed] 
53. Bonacorso, H.G.; Righi, F.J.; Rodrigues, I.R.; Cechinel, C.A.; Costa, M.B.; Wastowski, A.D.; Martins, M.A.P.; Zanatta, N. New efficient approach for the synthesis of 2-alkyl(aryl) substituted 4H-pyrido[1,2-a]pyrimidin-4-ones. J. Heterocycl. Chem. 2006, 43, 229-233. [CrossRef]

54. Roslan, I.I.; Lim, Q.-X.; Han, A.; Chuah, G.-K.; Jaenicke, S. Solvent-Free Synthesis of 4H-Pyrido[1,2-a]pyrimidin-4-ones Catalyzed by BiCl3: A Green Route to a Privileged Backbone. Eur. J. Org. Chem. 2015, 2351-2355. [CrossRef]

55. Mathavan, S.; Durai Raj, A.K.; Yamajala, R.B.R.D. A Metal-free Approach for the Synthesis of Privileged 4H-pyrido[1,2a]pyrimidin-4-one Derivatives over a Heterogeneous Catalyst. ChemistrySelect 2019, 4, 10737-10741. [CrossRef]

56. Yu, T.; Li, N.; Wu, C.; Guan, A.; Li, Y.; Peng, Z.; He, M.; Li, J.; Gong, Z.; Huang, L.; et al. Discovery of pyridopyrimidinones as potent and orally active dual inhibitors of PI3K/mTOR. ACS Med. Chem. Lett. 2018, 9, 256-261. [CrossRef]

57. Yan, H.; Ma, Y.; Sun, Y.; Ma, C.; Wang, Y.; Ren, X.; Huang, G. Catalyst-free synthesis of alkyl 4-oxo-4H-pyrido [1, 2-a] pyrimidine2-carboxylate derivatives on water. Tetrahedron 2014, 70, 2761-2765. [CrossRef]

58. Blackaby, W.; Brookfield, F.; Bubert, C.; Hardick, D.; Ridgill, M.; Shepherd, J.; Thomas, E. METTL3 Inhibitory Compounds. Patent WO2020201773A1, 8 October 2020.

59. Kinzel, O.D.; Ball, R.G.; Donghi, M.; Maguire, C.K.; Muraglia, E.; Pesci, S.; Rowley, M.; Summa, V. 3-Hydroxy-4-oxo-4H-pyrido[1,2a]pyrimidine-2-carboxylates-fast access to a heterocyclic scaffold for HIV-1 integrase inhibitors. Tetrahedron Lett. 2008, 49, 6556-6558. [CrossRef]

60. Donghi, M.; Kinzel, O.D.; Summa, V. 3-Hydroxy-4-oxo-4H-pyrido[1,2-a]pyrimidine-2-carboxylates-A new class of HIV-1 integrase inhibitors. Bioorg. Med. Chem. Lett. 2009, 19, 1930-1934. [CrossRef]

61. Muraglia, E.; Kinzel, O.; Gardelli, C.; Crescenzi, B.; Donghi, M.; Ferrara, M.; Nizi, E.; Orvieto, F.; Pescatore, G.; Laufer, R.; et al. Design and Synthesis of Bicyclic Pyrimidinones as Potent and Orally Bioavailable HIV-1 Integrase Inhibitors. J. Med. Chem. 2008, 51, 861-874. [CrossRef] [PubMed]

62. Kinzel, O.D.; Monteagudo, E.; Muraglia, E.; Orvieto, F.; Pescatore, G.; Rico Ferreira, M.; Rowley, M.; Summa, V. The synthesis of tetrahydropyridopyrimidones as a new scaffold for HIV-1 integrase inhibitors. Tetrahedron Lett. 2007, 48, 6552-6555. [CrossRef]

63. Crescenzi, B.; Kinzel, O.; Muraglia, E.; Orvieto, F.; Pescatore, G.; Rowley, M.; Summa, V. Patent WO2004058757A1, 15 July 2004.

64. Koch, U.; Attenni, B.; Malancona, S.; Colarusso, S.; Conte, I.; Di Filippo, M.; Harper, S.; Pacini, B.; Giomini, C.; Thomas, S.; et al. 2-(2-Thienyl)-5, 6-dihydroxy-4-carboxypyrimidines as inhibitors of the hepatitis C virus NS5B polymerase: Discovery, SAR, modeling, and mutagenesis. J. Med. Chem. 2006, 49, 1693-1707. [CrossRef]

65. Zhong, Y.-L.; Zhou, H.; Gauthier, D.R., Jr.; Askin, D. Efficient synthesis of functionalized pyrimidones via microwave-accelerated rearrangement reaction. Tetrahedron Lett. 2006, 47, 1315-1317. [CrossRef]

66. Tisler, M.; Zupet, R. An improved synthesis of dimethyl diacetoxyfumarate and its condensation with heterocyclic amines. Org. Prep. Proced. Int. 1990, 22, 532-534. [CrossRef]

67. Jones, E.D.; Vandegraaff, N.; Le, G.; Choi, N.; Issa, W.; Macfarlane, K.; Thienthong, N.; Winfield, L.J.; Coates, J.A.V.; Lu, L.; et al. Design of a series of bicyclic HIV-1 integrase inhibitors. Part 1: Selection of the scaffold. Bioorg. Med. Chem. Lett. 2010, 20, 5913-5917. [CrossRef]

68. Deadman, J.J.; Jones, E.D.; Le, G.T.; Rhodes, D.I.; Thienthong, N.; Vandegraff, N.; Winfield, L.J. Compounds Having Antiviral Properties. Patent WO2010000032A1, 7 January 2010.

69. Le, G.; Vandegraff, N.; Rhodes, D.I.; Jones, E.D.; Coates, J.A.V.; Lu, L.; Li, X.; Yu, C.; Feng, X.; Deadman, J.J. Discovery of potent HIV integrase inhibitors active against raltegravir resistant viruses. Bioorg. Med. Chem. Lett. 2010, 20, 5013-5018. [CrossRef]

70. Heath, D.G.; Rees, C.W. Reaction of 1,2,4-triazolo[4,3-a]pyridine with dimethyl acetylenedicarboxylate: New structures and mechanisms. J. Chem. Soc. Chem. Comm. 1982, 21, 1280-1282. [CrossRef]

71. Liang, Y.-F.; Steinbock, R.; Münch, A.; Stalke, D.; Ackermann, L. Manganese-Catalyzed Carbonylative Annulations for RedoxNeutral Late-Stage Diversification. Angew. Chem. Int. Ed. 2018, 57, 5384-5388. [CrossRef] [PubMed]

72. Huisgen, R.; Frauenberg, K.; Sturm, H.J. Cycloadditionen von pyridyl-und pyrimidyl-aziden. Tetrahedron Lett. 1969, 30, $2589-2594$. [CrossRef]

73. Bergnes, G.; Chabala, J.C.; Dhanak, D.; Knight, S.D.; Mcdonald, A.; Morgans, D.J.; Zhou, H.-J. Compounds, Compositions and Methods. Patent WO2004064741A2, 5 August 2004.

74. Ang, K.H.; Cox, M.; Lawrance, W.D.; Prager, R.; Smith, J.A.; Staker, W. Triplet lifetimes, solvent, and intramolecular capture of isoxazolones. Aust. J. Chem. 2004, 57, 101-105. [CrossRef]

75. Mátyus, P.; Ôsapay, K.; Gabányi, Z.; Kasztreiner, E.; Sohár, P. Kísérletek amino-diazinok két nukleofil reakciójának kvantumkémiai értelmezésére. Kem. Kozl. 1986, 66, 203-212.

76. Mátyus, O.; Szilágyi, G.; Kasztreiner, E.; Rabloczky, G.; Sohár, P. Some aspects of the chemistry of pyrimido[1,2-B]pyridazinones. J. Heterocycl. Chem. 1988, 25, 1535-1542. [CrossRef]

77. Gerorge, V.M.; Khetan, K.S.; Gupta, K.R. Advances in Heterocyclic Chemistry; Keritzky, R.A., Boulton, J.A., Eds.; Academic Press: New York, NY, USA; San Francisco, CA, USA; London, UK, 1976; Volume 19, p. 280.

78. Boer, R.F.; Petra, D.G.I.; Wanner, M.J.; Boesaart, A.; Koomen, G.J. Nucleos. Nucleot. 1995, 14, 349-352.

79. Liu, K.-C.; Huang, H.-S. Synthesis of methyl 4 (1H)-oxopyrimido[1,2-a]perimidine-2-carboxylate. Arch. Pharm. 1988, 321, 771-772. [CrossRef]

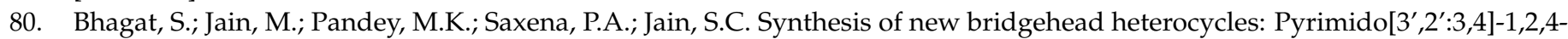
triazino[5,6-b]indoles. Heteroat. Chem. 2006, 17, 272-276. [CrossRef] 
81. Boyarintseva, O.N.; Kurilo, G.N.; Anisimova, O.S.; Grinev, A.N. Reaction of 3-aminoindole-2-carboxylic acids with an acetylenedicarboxylate ester. Khim. Geterotsikl. 1977, 1, 82-84.

82. Meyer, M.; Guyot, M. Synthesis of 2-substituted indolopyridin-4-ones. Tetrahedron Lett. 1996, 37, 4931-4932. [CrossRef]

83. Silva, A.M.G.; Castro, B.; Rangel, M.; Silva, A.M.S.; Brandão, P.; Felix, V.; Cavaleiro, J.A.S. Microwave-enhanced synthesis of novel pyridinone-fused porphyrins. Synlett 2009, 1009-1013. [CrossRef]

84. Nakazumi, H.; Endo, T.; Nakaue, T.; Kitao, T. Synthesis of 4,10-dihydro-4,10-dioxo-1H[1]benzothiopyrano[3,2-B]pyridine and 7-oxo-7,13-dihydro[1] benzothiopyrano[2,3-b]-1,5-benzodiazepine. J. Heterocycl. Chem. 1985, 22, 89-92. [CrossRef]

85. Baron, B.M.; Harrison, B.L. Certain Quinolines and Thienopyridines as Excitatory Amino Acid Antagonists. Patent US5026700A, 25 June 1991.

86. Goerlitzer, K.; Kramer, C. Potential antiallergics. 3. Synthesis and transformations of 1, 4-dihydro-4-oxo-(1) benzothieno (3, 2-b) pyridine-2-carboxylic acid esters. Pharmazie 2000, 9, 645-650. [CrossRef]

87. Barker, J.M.; Huddleston, P.R.; Jones, A.W.; Edwards, M. Thienopyridines. Part 2. Application of the Conrad-Limpach and Gould-Jacobs reactions to the synthesis of thieno[3,4-b]pyridin4(1H)-ones. J. Chem. Res. S. 1980, 1, 4-5.

88. Connor, D.T.; Young, P.A.; Strandtmann, M. Synthesis of 4,10-dihydro-4,10-dioxo-1H-[1]-benzopyrano[3,2-b]pyridine, 4,5Dihydro-4,5-dioxo-1H-[1]-benzopyrano[2,3-6]pyridine and 1,5-Dihydro-1,5-dioxo-4H-[1]-benzopyrano[3,4-b]pyridine derivatives from aminobenzopyrones. J. Heterocycl. Chem. 1981, 18, 697-702. [CrossRef]

89. Dorokhov, V.A.; Vasilyev, A.V.; Baranin, S.V. Synthesis of 3-acetyl-4-amino-6-arylpyran-2-ones and ethyl 7-aryl-4,5(1H, 5H)dioxopyrano[4,3-b]pyridine-2-carboxylates. Russ. Chem. Bull. 2002, 51, 503-505. [CrossRef]

90. Connor, D.T. 1,5-Dihydro-1,5-dioxo-N-1H-tetrazol-5-yl-4H-[1]benzopyrano[3,4-b]pyridine-3-Carboxamides and Process Thereof. Patent US4198511A, 15 April 1980.

91. Goerlitzer, K.; Kramer, C. Potenzielle Antiallergika: Darstellung und Reaktionen von 1,4-Dihydro-4-oxo-[1]benzofuro[3, 2b]pyridin-2-carbonsäureestern. Pharmazie 2000, 8, 587-594.

92. Fehér, E.; Szatmári, I.; Dudás, T.; Zalatnai, A.; Farkas, T.; Lőrinczi, B.; Fülöp, F.; Vécsei, L.; Toldi, J. Structural evaluation and electrophysiological effects of some kynurenic acid analogs. Molecules 2019, 24, 3502. [CrossRef] [PubMed]

93. Hall, M.C.; Johnson, G.H.; Wright, B.J. Quinoline derivatives as antiallergy agents. J. Med. Chem. 1974, 17, 685-690. [CrossRef] [PubMed]

94. Bryant, J.A.; Buckman, B.O.; Islam, I.; Mohan, R.; Morrissey, M.M.; Wei, G.P.; Wei, X.; Yuan, S. Platelet Adenosine Diphosphate Receptor Antagonists. Patent US2003060474A1, 27 March 2003.

95. Lőrinczi, B.; Csámpai, A.; Fülöp, F.; Szatmári, I. Synthetic-and DFT modelling studies on regioselective modified Mannich reactions of hydroxy-KYNA derivatives. RSC Adv. 2021, 11, 543. [CrossRef]

96. Sloan, N.L.; Luthra, S.K.; McRobbie, G.; Pimlott, S.L.; Sutherland, A. Late stage iodination of biologically active agents using a one-pot process from aryl amines. RSC Adv. 2017, 7, 54881-54891. [CrossRef]

97. Szatmári, I.; Fülöp, F. Syntheses, transformations and applications of aminonaphthol derivatives prepared via modified Mannich reactions. Tetrahedron 2013, 69, 1255-1278. [CrossRef]

98. Szatmári, I.; Fülöp, F. Microwave-Assisted One-Pot Synthesis of (Aminoalkyl)naphthols and (Aminoalkyl)quinolinols by Using Ammonium Carbamate or Ammonium Hydrogen Carbonate as Solid Ammonia Source. Synthesis 2009, 5, 775-778. [CrossRef]

99. Szatmári, I.; Fülöp, F. Simple access to pentacyclic oxazinoisoquinolines via an unexpected transformation of aminomethylnaphthols. Tetrahedron Lett. 2011, 52, 4440-4442. [CrossRef]

100. Sas, J.; Szatmári, I.; Fülöp, F. C-3 functionalization of indole derivatives with isoquinolines. Curr. Org. Chem. 2016, 20, 2038-2054.

101. Lőrinczi, B.; Csámpai, A.; Fülöp, F.; Szatmári, I. Synthesis of new C-3 substituted kynurenic acid derivatives. Molecules 2020, 25, 937. [CrossRef] [PubMed] 